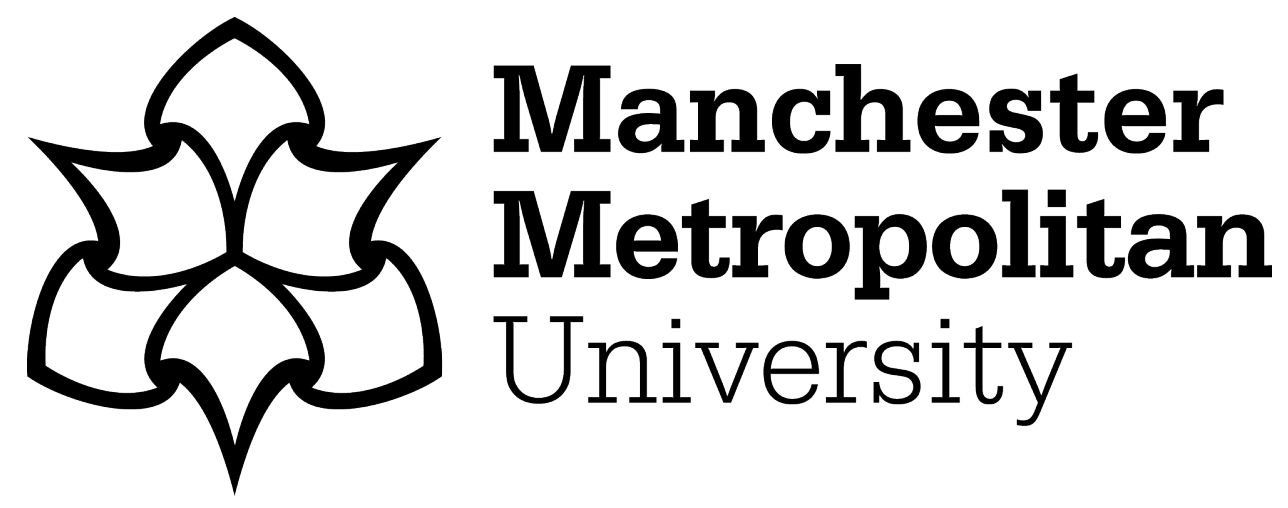

Comfort, P, Dos'Santos, T, Beckham, GK, Stone, MH, Guppy, SN and Haff, GG (2019) Standardization and methodological considerations for the isometric midthigh pull. Strength and Conditioning Journal, 41 (2). pp. 57-79. ISSN 1524-1602

Downloaded from: https://e-space.mmu.ac.uk/626030/

Version: Accepted Version

Publisher: National Strength and Conditioning Association

DOI: https://doi.org/10.1519/SSC.0000000000000433

Usage rights: Creative Commons: Attribution-Noncommercial 4.0

Please cite the published version 
See discussions, stats, and author profiles for this publication at: https://www.researchgate.net/publication/328498794

\section{Standardization and Methodological Considerations for the Isometric Midthigh Pull}

Article in Strength and conditioning journal · October 2018

DOI: $10.1519 /$ SSC.0000000000000433

\section{CITATIONS}

16

6 authors, including:

Paul Comfort

University of Salford

215 PUBLICATIONS 2,264 CITATIONS

SEE PROFILE

George Beckham

California State University, Monterey Bay

40 PUBLICATIONS 466 CITATIONS

SEE PROFILE
READS

684

Thomas Dos'Santos

Manchester Metropolitan University

66 PUBLICATIONS 508 CITATIONS

SEE PROFILE

1. Michael Henry Stone

East Tennessee State University

427 PUBLICATIONS 13,307 CITATIONS

SEE PROFILE

Some of the authors of this publication are also working on these related projects:

High Volume Resistance Training and its Effects on High Intensity Exercise Endurance View project

Thesis View project 
Standardization and methodological considerations for the Isometric Mid-Thigh Pull

Paul Comfort ${ }^{1, \#}$, Thomas Dos'Santos ${ }^{1}$, George K. Beckham ${ }^{2}$, Michael H. Stone ${ }^{3}$, Stuart. N. Guppy $^{4}$, G. Gregory Haff ${ }^{4}$.

${ }^{1}$ Directorate of Sport, Exercise and Physiotherapy, University of Salford, Salford, Greater Manchester, UK

${ }^{2}$ Kinesiology Department, California State University, Monterey Bay, Seaside, CA.

${ }^{3}$ Center of Excellence for Sport Science and Coach Education, Department of Exercise and Sport Science, East Tennessee State University, Johnson City, TN.

${ }^{4}$ Centre for Exercise and Sports Science Research, Edith Cowan University, Joondalup, Australia

\#Corresponding Author - p.comfort@ salford.ac.uk 


\section{Abstract}

2 The isometric mid-thigh pull (IMTP) is commonly used to assess an athlete's force

3 generation ability. This test is highly reliable and is simple and relatively quick to perform.

4 The data that can be determined from the force-time curves generated by the test have been

5 shown to be closely related to performance capacities in a variety of dynamic athletic tasks.

6 However, within the scientific literature there are inconsistencies in the data collection

7 procedures and methods used for data analysis that may impact the resultant output and the

8 ability to compare and generalize results. Therefore, the primary aim of this review is to

9 identify the differences in IMTP testing procedures and data analysis techniques, while

10 identifying the potential impact this may have on the data collected. The secondary aim is to

11 provide recommendations for the standardization of testing procedures to ensure that future

12 IMTP data is of maximal benefit to practitioners and researchers.

14 Keywords: Force; Rate of Force Development; Posture; Isometric Strength 
Maximal strength underpins performance in many athletic tasks $(15,55,63)$ and as such, monitoring strength, usually by repetition maximum (RM) testing, is commonly performed by practitioners and researchers. While RM testing is reliable $(12,24,28)$, it can be perceived as fatiguing, posing an increased potential for injury risk, and only providing information related to the maximal load lifted. In contrast, isometric testing, such as the isometric midthigh pull (IMTP), is potentially safer (18), less fatiguing, and allows for the quantification of peak force (PF), force at a variety of epochs, and can provide several measures of the rate of force development (RFD) $(11,21,26,30,32,33)$. The diagnostic ability of these measures may be of importance when considering time constrained tasks within sports, such as jumping, sprinting and change of direction. Importantly, the IMTP has been shown to be highly reliable both within and between sessions, with low variability and low measurement error $(8,11,18,24,26,27,32)$.

Performance in the IMTP has been associated with performance in numerous athletic tasks $(7,18,30,33,40,41,45,46,49,59,64,66,67,69,72,73)$. Specifically, absolute PF has been associated with weightlifting performance $(7,30), 1 \mathrm{RM}$ squat and power clean $(45-47$, 49, 59, 69, 73), 1RM deadlift (18), vertical jump performance (39-41, 53, 60, 64, 67), short sprint and change of direction times $(59,64)$, sprint cycling performance $(60)$, and throwing performance (72) (Table 1). In contrast, West et al. (71) reported no meaningful relationships between absolute PF and short sprint times or jump height, although they did observe large correlations between relative $\mathrm{PF}$ (PF/body weight) and these variables in rugby league players. Similarly, Nuzzo et al. (49) reported only a small relationship between absolute PF and jump height but a large relationship between relative PF and jump height (Table 1). The range of associations between PF and performance in other tasks is summarized in Figure 1. 
performance in athletic tasks $(60,72)$, demonstrating similar correlations to those observed when ratio scaling is used (60).

[Insert table 1 about here]

43

[Insert figure 1 about here]

Another way to examine the isometric force-time curve is to measure force at specific time epochs (e.g. 50-250 ms). It has been reported that these time specific forces are associated with squat jump (SJ) and countermovement jump (CMJ) height (force at 50-, 90, $250 \mathrm{~ms}$ ) (41), weightlifting performance (force at 100-, 150-, 200-, $250 \mathrm{~ms}$ ) (7) and 1RM back squat (90-250 ms) (69). Additionally, allometrically scaled force at $150 \mathrm{~ms}$ was reported to be related to mean and maximum club head speed during a golf swing (42), with allometrically scaled force at 50-, 90- and $250 \mathrm{~ms}$ also related to jump performance (41) (Table 2). In contrast, however, force at 30-250 ms was not related to 1RM deadlift performance (18).

54

55

[Insert table 2 about here]

56 Equivocal results regarding the relationships between measures of RFD and performance in dynamic athletic tasks have been reported in the scientific literature. When examining how the RFD is quantified two main methods exist within the literature (32). The first method is to quantify the peak RFD (PRFD) that occurs during the IMTP with a predefined moving 60 window, most typically lasting between 2-40 ms (32) (Table 3). When this method is utilized for analyzing the force-time curve conflicting results exist within the scientific literature with 
62

63

64

65

66

67

68

69

70

71

72

73

74

75

76

77

78

79

80

81

82

83

84 isometric impulse $(67,68)$. For example, impulse values across different epochs $(0-100,0$ 85

some authors reporting significant relationships between the RFD and dynamic performance activities $(30,33,39,41)$, while others report no meaningful relationship with 1RM performance (7, 45-47), or SJ and CMJ performances $(40,49,67)$. These difference may be attributable to the moving window, with Maffiuletti et al. (43) cautioning against the use of short windows (e.g. $2 \mathrm{~ms}$ ) as they may be too sensitive to unsystematic variability and therefore less reliable. The second method for evaluating the RFD is to examine time dependant epochs (32). The use of time dependent epoch has been shown to be an effective method for examining the RFD during the IMTP and relating it to various sports performance tasks. For example, Spiteri et al. (58) report that athletes who produce higher RFD to $90 \mathrm{~ms}$ and $100 \mathrm{~ms}$ are able to demonstrate faster agility times during a $45^{\circ}$ cutting task. One possible explanation why some RFD measures relate to dynamic performance activities and others do not is the method of calculation and reliability of the method. For example, Haff et al. (32) have shown that the only PRFD measure that is reliable is when a $20 \mathrm{~ms}$ moving window is used, supporting previous suggestions by Maffiuletti et al. (43). Conversely, using time dependent epochs such as 0-90 ms, 0-150 ms, 0-200 ms and 0-250 ms to calculate the mean RFD across the specific duration produces much more reliable results and generally have better relationships to dynamic performance measures. Therefore, it is generally recommended that using time specific RFD epochs is warranted when using the IMTP as a performance diagnostic tool (32).

[Insert table 3 about here]

Another method for analysing the force-time curve derived from an IMTP is to examine the 200 and 0-300 ms) have been associated with 5- and $20 \mathrm{~m}$ sprint times as well as 505 change 
of direction times (64), peak force and power during the SJ and CMJ (68) (Table 4). While

87

88 determining the isometric impulse of various epochs within the force-time curve achieved during the IMTP yields useful information much more research is needed to understand how best to utilise this measurement in a sports performance monitoring program.

[Insert table 4 about here]

The PF achieved during the IMTP has also been used to monitor adaptations to training (5, $36,50,51,57,70,74)$, with some authors also including RFD $(36,51,52,74)$. PF and peak RFD have also been used in an attempt to identify levels of fatigue or recovery $(4,29,35$, 44). More recently researchers have started to investigate the potential of the IMTP to investigate between-limb asymmetries, using dual force platforms (1-3) and a unilateral stance IMTP $(25,65)$. Additionally, the PF during the IMTP has been divided by the PF during a SJ or CMJ, to calculate the dynamic strength index (DSI; ratio of PF during the CMJ or SJ and IMTP PF), in attempt to identify if an athlete needs to focus more on maximal force production or rapid dynamic force production $(14,52,54,56,66)$.

\section{Variation in Testing and Data Analysis Procedures}

Unfortunately, there is substantial variation across testing protocols reported within the scientific literature, including differences in knee and hip joint angles (120-150 and 124$175^{\circ}$, respectively), sampling frequency $(500-2000 \mathrm{~Hz})$, pull onset identification thresholds including absolute $(20-75 \mathrm{~N})$ and relative $(2.5-10 \%$ body weight) threshold values, and smoothing and filtering approaches, with some authors not stating hip angles, thresholds or filtering procedures (Table 5). In addition, if practitioners or researchers are intending to use 
109

110

111

112

published values for comparison they should be mindful that some data is presented as net force (gross force - body weight) while others report gross measures, along with ratio and allometric scaling used in some studies. These two latter approaches may impact the results less, as allometric scaling uses an exponent related to body mass (13) although allometric scaling will reduce the resultant values compared to ratio scaling, with greater variation introduced depending on the exponent used (Table 5).

[Insert table 5 about here]

Numerous authors have suggested that the posture adopted during the IMTP should replicate the start of the second pull phase of the clean, $(30,31,33,60)$; however, only two studies have actually assessed the participants knee joint angles during the clean and then adopted these angles during the IMTP $(30,31)$. This is most likely due to time and practicality of assessing specific joint angles during the clean prior to performing the IMTP, especially when assessing large squads of athletes. Interestingly, hip joint angles were not reported within these two studies $(30,31)$.

Due to the variety of knee and hip joint angles reported within the literature, Comfort et al. (11) investigated a range of knee $\left(120^{\circ}, 130^{\circ}, 140^{\circ}, 150^{\circ}\right)$ and hip $\left(125^{\circ}, 145^{\circ}\right)$ joint angles, along with self-selected posture (knee $133 \pm 3^{\circ}$, hip $138 \pm 4^{\circ}$ ) based on the athletes preferred position to start the second pull of a clean, which is what the posture adopted during the IMTP was originally based on (33). The results of the study indicated that there were no significant or meaningful differences in PF, PRFD or impulse between postures, although the preferred (self-selected) posture demonstrated the highest reliability and the lowest 
measurement error. In contrast, Beckham et al. (6) found that powerlifters produced greater PF during an isometric testing with a vertical torso compared to a deadlift-specific body position at the same bar height, described as being a "relatively straight legged position and somewhat bent over the bar". The authors suggested that the upright position may have provided a mechanical advantage and a posture more optimal for force production against the bar. In another study, Beckham et al. (8) compared the effects of different hip joint angles $\left(125^{\circ}\right.$ vs. $\left.145^{\circ}\right)$, while standardizing the knee joint angle $\left(125^{\circ}\right)$ reporting meaningful and significantly higher PF and force at different epochs $(50,90,200,250 \mathrm{~ms})$ in the more upright $\left(145^{\circ}\right)$ position, especially in subjects with greater experience in performing weightlifting exercises and their derivatives, in contrast to Comfort et al. (11). Interestingly, Beckham et al. (8) reported small changes in joint angles throughout the execution of the test and based on these observations recommend that in the future researchers and practitioners should adopt standardized knee and hip angles of $120-135^{\circ}$ and $140-150^{\circ}$, respectively.

145 More recently, Dos'Santos et al. (26) compared hip joint angles of $145^{\circ}$ and $175^{\circ}$ with a standardized knee joint angle of $145^{\circ}$, finding greater time specific force values and RFD at 147 predetermined epochs, with a $145^{\circ}$ hip angle (Table 5). The hip angle of $175^{\circ}$ previously 148 reported by Kraska et al. (41) and replicated by Beckham et al. (6) actually refer to trunk 149 angle relative to vertical, to ensure an upright trunk (forward lean of $5^{\circ}$ from vertical), exhibiting an upright trunk as previously described $(30,31,33,60)$ rather than a $175^{\circ}$ hip angle as used by Dos'Santos et al. (26). The authors of a recent meta-analysis also highlight the fact the practitioners should carefully consider the specific protocol, including joint angles, to ensure repeatability of the measures (27).

154 While adopting standardized knee and hip angles during the IMTP may seem logical, this practice may place athletes in a sub-optimal pulling position, due to the range of angles reported across individuals for the second pull phase of the clean $(30,31)$. Therefore, it is 
157

158

159

160

161

162

163

164

165

166

167

168

169

170

171

172

173

174 Interestingly, numerous authors state that they have adopted the postures previously reported 175 176

177

178

179

best to consider the individual athletes' appropriate second pull position and then quantify the knee and hip angles. This practice allows for the individual athlete's anthropometrics to be considered and allows them to assume an optimal pulling position, in line with the range of joint angles recommended by Beckham et al. (8). Once the pulling position is established then it is recommended that practitioners and researchers ensure that the individual starting postures are replicated between trials and testing sessions. Joint angles should be assessed prior to the commencement of the pull due to slight changes in joint angles during the pull (8).

Haff et al. (32) suggest using minimal pre-tension prior to initiation of the pull, as this is likely to impact both time specified force and RFD, with Dos'Santos et al. (26) recently reporting that the $175^{\circ}$ hip angle results in significantly higher 'body weight' due to increased pre-tension, compared to a $145^{\circ}$ hip angle, which may have contributed to in the differences in time specific force values and RFD that were reported. Similarly, Maffiuletti et al. (43) suggested that pre-tension is undesirable when assessing isometric RFD, albeit with a focus on single joint assessment; it would, therefore, be advantageous to visually inspect the forcetime data pre and post isometric pull, to ensure that there are no differences in force, which should represent body weight.

by other researchers, but in fact report different angles to those stated in the studies that they cite, or cite multiple researchers who reported different postures (Table 5). These differing postures are most likely related to individual athlete anthropometric profiles. It is therefore important that researchers carefully report and justify their choice of joint angles, but more importantly, standardize these between trials and testing sessions. 
180 Other researchers have used strain gauge based equipment, with the handle attached via a 181 chain $(16,17,37,38,48)$ with a range of sampling frequencies $(100-133 \mathrm{~Hz}(17,37,38))$ and joint angles (knee 120-130 $(17), 142 \pm 4^{\circ}(38), 143 \pm 7^{\circ}$ (37), $160^{\circ}$ (48); hip 139 $\pm 4^{\circ}$ (38),

$\left.183144 \pm 5^{\circ}(37)\right)$. However, findings of two research groups that compared strain gauge systems 184 to a force platform demonstrated that the strain gauge significantly underestimated PF, by $185 \sim 8 \%$ (38) to $~ 10 \%$ (20). Additionally, James et al. (38) found that measures of RFD did not meet acceptable standards of reliability. While such systems can measure PF, which can be ratio or allometrically scaled, there does not seem to be an effective way to accurately measure or calculate RFD, and are therefore not recommended if practitioners have access to a force platform.

\section{Recommendations for Correct IMTP Assessment}

Due to the noticeable variations in assessment procedures, including posture, sampling frequency, and methods of calculating specific variables (namely use of different sampling frequencies, onset thresholds, and the method for the calculation of RFD), we suggest appropriate standardization of all testing procedures for the IMTP. Such standardization should permit more meaningful comparisons of individual performances between testing sessions, comparisons between athletes and more effective comparisons between published studies. Standardization should also include the verbal cues as attentional focus has been shown to affect force production, with an external focus of 'push as hard and fast as possible' resulting in greater PF compared to an internal focus (34). 
204 Prior to initiation of IMTP testing, the bar height necessary to obtain the correct body 205 position should be determined. This should be an iterative process in which the athlete starts 206 with a bar height that allows the athlete to assume a body position that replicates the start of 207 the second pull position during the clean. The bar height should then be adjusted up or down to allow the athlete to obtain the optimal knee $\left(125-145^{\circ}\right)$ and hip $\left(140-150^{\circ}\right)$ angles $(6,8$, 26). The body position should be very similar to the second pull of the clean and the clean

210 grip mid-thigh pull exercise (19): upright torso, slight flexion in the knee resulting in some 211 dorsiflexion, shoulder girdle retracted and depressed, shoulders above or slightly behind the vertical plane of the bar, feet roughly centered under the bar approximately hip width apart,

213 knees underneath and in front of the bar, and thighs in contact with the bar (close to the

214 inguinal crease dependent on limb lengths) (Figure 2). When making joint measurements, the 215 athlete should ensure that no tension is applied to the bar but that all "slack" (e.g. elbow 216 flexion, shoulder girdle elevation/protraction) is removed from the body, as this would result 217 in a change in joint angles during the maximal effort which is undesirable (8).

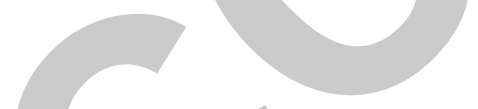

\section{[Insert figure 2 about here]}

While the use of a "self-selected" body position is likely beneficial to efficiency of testing, it is not recommended without ensuring that the hip and knee joint angles fall within the ranges recommended above, due to the influence of body positioning on force generation $(6,8,26)$. The bar height used and joint angles obtained should be recorded so that repeated measurements can be standardized and therefore replicate the individuals' body position 
between session, ensuring that differing results in subsequent testing are not the result of

227

228

229

230

231

232

233

234

235

236

237

238

239

240

241

242

243

244

245

246

247

248

249 changed body position $(8,26)$. It is also considered best practice to measure the individuals grip width and foot position and standardize these for individuals across sessions (unless working with youth athletes where changes in stature as a result of maturation may require increased stance and grip width) as each can affect body positioning relative to the bar (19). After the bar height and posture have been established, a short familiarization session of submaximal trials is recommended approximately 48 hours prior to testing (e.g. 3 x 3 second trials, each of 50-, 75- and $90 \%$ of perceived maximum effort). While a consensus on the optimal amount of familiarization has not yet been reached, nearly all IMTP studies use some familiarization.

Athletes should complete some manner of standard generalized warm-up (62). While there is variability in the generalized warm-up chosen among studies, most studies use a warm-up that incorporates clean derivatives, such as the dynamic mid-thigh pull, and should thus be a component of the standard warm-up $(7,21,24,32,33)$. Submaximal trials of the IMTP are also recommended prior to maximal effort trials (e.g. 3 seconds each of: $50 \%$ maximal effort, $75 \%$ maximal effort, $90 \%$ maximal effort, separated by 60 seconds rest). During this time, the athlete should be secured to the bar using lifting straps and athletic tape to ensure that grip strength is not a limiting factor (Figure 3) (30, 33).

[Insert figure 3 about here]

For each of the maximal effort trials, standardized instructions should be given to the athlete of some iteration of "push your feet into the ground as fast and as hard as possible" to ensure that both maximal RFD and PF are obtained $(10,34)$. It is essential that athletes understand that the focus is to drive the feet directly into the force platform and not attempt to pull the 
bar with the arms, or rise up on to their toes. The athlete should get into the correct body position for the IMTP, using just enough pre-tension to achieve the correct body position and remove "slack" from the body, but without any more pre-tension than is necessary to get the "quiet standing" necessary for a stable force baseline (43). This can be verified by monitoring

254 the athlete's body positioning and ensuring the force trace created by the athlete is both similar to body mass and steady, with trials where a change in force $>50 \mathrm{~N}$ occurs during this period rejected (21). This should be explained to the athletes and they should be encouraged to stay as still as possible during this period to accurately determine body weight and onset threshold. A countdown of " $3,2,1$, PULL!" gives the athlete sufficient warning to be ready to give a maximum effort and provides at least one second of quiet standing to enable the identification of the onset of the pull (Figure 5a). Strong verbal encouragement from researchers and teammates ensures that the athlete gives a maximum effort (9). A minimum of two trials should be collected, provided that each of those trials have no errors by the athlete (e.g. countermovement, excessive pre-tension, leaning on the bar prior to the pull (Figure 4). With increasing PF, additional trials should be performed, until the PF values of the trials are separated by $<250 \mathrm{~N}(30,33)$. It is noted, however, that a percentage of peak force may be advantageous as an absolute value will affect stronger and weaker athletes differently, although the exact effect of this has not been investigated.

[Insert figure 4 about here]

Visual inspection of the force-time curves during testing can easily be used to determine if the trials are acceptable, or if additional trials should be performed. In addition to the trials

272 being within $250 \mathrm{~N}$ between attempts, trials should be repeated if there is not a stable weighing period (clear fluctuation in the force-time data) or a clear countermovement prior to 
the initiation of the pull (Figure 5c), as this will interfere with accurate identification of the initiation of the pull (19), or if the PF occurs at the end of the trial (Figure 5b). It is also important to check that the force during the initial period of quiet standing (in the ready

277 position, strapped to the bar, immediately prior to commencing the pull) represents body 278 weight, and therefore no prior tension has been applied (Figure 5a) as this will interfere with pull onset identification (19).

\section{Recommended Data Analysis and Reporting}

284 285

Collection of IMTP force-time data can be compiled accurately with a sampling frequency as low as $500 \mathrm{~Hz}$, but if higher sampling frequencies can be used then they are preferred as they may increase the accuracy of time dependent measures (21). Specifically, the utilization of frequencies $\geq 1000 \mathrm{~Hz}$ are recommended especially if early force-time variables are of interest (e.g. force at 50 or $100 \mathrm{~ms}$ ) (21). There are not enough data for a consensus regarding optimal filtering and/or smoothing methods for the IMTP (23); although unfiltered data has been suggested as optimal for analysis of countermovement jump performance (61) and where possible, unfiltered data for isometric testing $(23,43)$. It is therefore suggested that unfiltered and non-smoothed data is used for subsequent analysis (23), as most of the RFD and impulse characteristics are dependent upon an accurate determination of the start of the pull (21), although data from portable force platforms may exhibit greater 'noise' and warrant smoothing. Accurate identification of the start of the inflection point is often achieved using automated methods - we recommend using 5 standard deviations of body weight during an 
initial one second weighing period prior to the (usually one second) of quiet standing (in the ready position, strapped to the bar, immediately prior to commencing the pull) as the threshold for determining the onset of the pull (21), although this may vary with technical idiosyncrasies of different force platforms (e.g. noise magnitude). Trials that do not have a

301 stable baseline force trace during the weighing period (change in force $>50 \mathrm{~N}$ ) should be rejected and subsequently another trial should be performed $(21,43)$ (Figure 5). To facilitate this stable period, it is essential to enforce and practice this during the warm-up / familiarization trials.

It is recommended that time-specific RFD epochs (50-, 100-, 150-, 200- and $250 \mathrm{~ms}$ commonly reported) should be used when using the IMTP as a sport performance diagnostic tool as these are not only reliable (32), but can be selected specific to the durations relevant to the specific sporting tasks, such as ground contact time during acceleration or peak running speeds. In contrast, maximal strength capabilities can be inferred from PF (Table 1).

When reporting results from IMTP testing, it is important that the hip and knee angles used

311 by each athlete, to establish the bar height, be reported $(8,26)$. Such standardization of

312 posture between trials and testing sessions ensures that data is comparable between sessions, groups of athletes and studies $(8,26)$. While there is no consensus as to the superiority of

314 either net or gross force values for the IMTP, it is important that researchers report whether

315 body weight was or was not included in the force and impulse values reported (7). Other 316 methodological considerations, such as the method for identifying the onset of the pull (and 317 threshold) (21), methods used for smoothing/filtering force platform data (23), sampling 318 frequency and other aspects of analysis (22), such as the exponent used for allometric scaling,

319 should be reported, as each are important for accurately interpreting results from the study. 


\section{References}

322 1. Bailey CA, Sato K, Alexander R, Chiang CY, and Stone M. Isometric force production symmetry and jumping performance in collegiate athletes. $J$ Trainology 2 : $1-5,2013$.

2. Bailey CA, Sato K, Burnett A, and Stone MH. Carry-over of force production symmetry in athletes of differing strength levels. J Strength Cond Res. 29: 3188-3196, 2015.

3. Bailey CA, Sato K, Burnett A, and Stone MH. Force-production asymmetry in male and female athletes of differing strength levels. Int J Sports Physiol Perform. 10: 504508, 2015.

4. Bartolomei S, Sadres E, Church DD, Arroyo E, Iii JAG, Varanoske AN, Wang R, Beyer KS, Oliveira LP, Stout JR, and Hoffman JR. Comparison of the recovery response from high-intensity and high-volume resistance exercise in trained men. Eur J Appl Physiol 117: 1287-1298, 2017.

5. Beattie K, Carson BP, Lyons M, and Kenny IC. The Effect of maximal- and explosive-strength training on performance indicators in cyclists. Int J Sports Physiol Perform 12: 470-480, 2017.

6. Beckham G, Lamont H, Sato K, Ramsey M, Haff GG, and Stone M. Isometric strength of powerlifters in key positions of the conventional deadlift. J Trainology 1, 2012.

7. Beckham G, Mizuguchi S, Carter C, Sato K, Ramsey M, Lamont H, Hornsby G, Haff $\mathrm{G}$, and Stone M. Relationships of isometric mid-thigh pull variables to weightlifting performance. J Sports Med Phys Fitness 53: 573-581, 2013.

8. Beckham GK, Sato K, Mizuguchi S, Haff GG, and Stone MH. Effect of body position on force production during the isometric mid-thigh pull. J Strength Cond Res. 32(1): 48-56: 18.

9. Belkhiria C, De Marco G, and Driss T. Effects of verbal encouragement on force and electromyographic activations during exercise. J Sports Med Phys Fitness 58: 750757, 2018.

10. Bemben MG, Clasey JL, and Massey BH. The effect of the rate of muscle contraction on the force-time curve parameters of male and female subjects. Res Q Exerc Sport 61: 96-99, 1990.

11. Comfort P, Jones PA, McMahon JJ, and Newton R. Effect of knee and trunk angle on kinetic variables during the isometric midthigh pull: test-retest reliability. Int J Sports Physiol Perform 10: 58-63, 2015.

12. Comfort $P$ and McMahon JJ. Reliability of maximal back squat and power clean performances in inexperienced athletes. J Strength Cond Res. 29: 3089-3096, 2015.

13. Comfort $\mathrm{P}$ and Pearson SJ. Scaling--which methods best predict performance? $J$ Strength Cond Res 28: 1565-1572, 2014.

14. Comfort P, Thomas C, Dos'Santos T, Jones PA, Suchomel TJ, and McMahon JJ. Comparison of methods of calculating dynamic strength index. Int J Sports Physiol Perform: 1-20, 2017.

15. Cormie P, McGuigan MR, and Newton RU. Developing maximal neuromuscular power: Part 1--biological basis of maximal power production. Sports Med 41: 17-38, 2011.

16. Crewther BT, Carruthers J, Kilduff LP, Sanctuary CE, and Cook CJ. Temporal associations between individual changes in hormones, training motivation and physical performance in elite and non-elite trained men. Biol Sport 33: 215-221, 2016. 
17. Davis GR, Gallien GJ, Moody KM, LeBlanc NR, Smoak PR, and Bellar D. Cognitive function and salivary DHEA levels in physically active elderly african american women. Int J Endocrinol 2015: 6, 2015.

18. De Witt JK, English KL, Crowell JB, Kalogera KL, Guilliams ME, Nieschwitz BE, Hanson AM, and Ploutz-Snyder LL. Isometric mid-thigh pull reliability and relationship to deadlift 1RM. J Strength Cond Res. 32 (2): 528-533. 2018.

19. DeWeese BH, Serrano AJ, Scruggs SK, and Burton JD. The midthigh pull: proper application and progressions of a Weightlifting movement derivative. Strength Cond $J$ 35: 54-58, 2013.

20. Dobbin N, Hunwicks R, Jones B, Till K, Highton J, and Twist C. Criterion and construct validity of an isometric mid-thigh pull dynamometer for assessing whole body strength in professional rugby league players. Int J Sports Physiol Perform. 13(2): 235-239. 2018.

21. Dos'Santos T, Jones PA, Comfort P, and Thomas C. Effect of different onset thresholds on isometric mid-thigh pull force-time variables. J Strength Cond Res 31: 3467-3473, 2017.

22. Dos'Santos T, Jones PA, Kelly J, McMahon JJ, Comfort P, and Thomas C. Effect of sampling frequency on isometric midthigh-pull kinetics. Int J Sports Physiol Perform 11: 255-260, 2016.

23. Dos'Santos T, Lake JP, Jones PA, and Comfort P. Effect of low pass filtering on isometric mid-thigh pull kinetics. J Strength Cond Res. 32: 983-989, 2018.

24. Dos'Santos T, Thomas C, Comfort P, McMahon JJ, Jones PA, Oakley NP, and Young AL. Between-session reliability of isometric mid-thigh pull kinetics and maximal power clean performance in male youth soccer players. J Strength Cond Res Published ahead of print, 2017.

25. Dos'Santos T, Thomas C, Jones PA, and Comfort P. Assessing muscle strength asymmetry via a unilateral stance isometric mid-thigh pull. Int J Sports Physiol Perform. 12(4): 505-511. 2017.

26. Dos'Santos T, Thomas C, Jones PA, McMahon JJ, and Comfort P. The effect of hip joint angle on isometric mid-thigh pull kinetics. J Strength Cond Res. 31(10):27482757. 2017

27. Drake D, Kennedy R, and Wallace E. The validity and responsiveness of isometric lower body multi-joint tests of muscular strength: a systematic review. Sports Med Open 3: 23, 2017.

28. Faigenbaum AD, McFarland JE, Herman RE, Naclerio F, Ratamess NA, Kang J, and Myer GD. Reliability of the one-repetition-maximum power clean test in adolescent athletes. J Strength Cond Res 26: 432-437, 2012.

29. Gescheit DT, Cormack SJ, Reid M, and Duffield R. Consecutive days of prolonged tennis match play: performance, physical, and perceptual responses in trained players. Int J Sports Physiol Perform. 10: 913-920, 2015.

30. Haff GG, Carlock JM, Hartman MJ, Kilgore JL, Kawamori N, Jackson JR, Morris RT, Sands WA, and Stone MH. Force-time curve characteristics of dynamic and isometric muscle actions of elite women olympic weightlifters. J Strength Cond Res 19: 741-748, 2005.

31. Haff GG, Jackson JR, Kawamori N, Carlock JM, Hartman MJ, Kilgore JL, Morris RT, Ramsey MW, Sands WA, and Stone MH. Force-time curve characteristics and hormonal alterations during an eleven-week training period in elite women weightlifters. J Strength Cond Res 22: 433-446, 2008. 
32. Haff GG, Ruben RP, Lider J, Twine C, and Cormie P. A comparison of methods for determining the rate of force development during isometric mid-thigh clean pulls. $J$ Strength Cond Res 29: 386-395, 2015.

33. Haff GG, Stone M, O'Bryant HS, Harman E, Dinan C, Johnson R, and Han K-H. Force-time dependent characteristics of dynamic and isometric muscle actions. $J$ Strength Cond Res. 11: 269-272, 1997.

34. Halperin I, Williams KJ, Martin DT, and Chapman DW. The effects of attentional focusing instructions on force production during the isometric midthigh pull. $J$ Strength Cond Res. 30: 919-923, 2016.

35. Helms ER, Zinn C, Rowlands DS, Naidoo R, and Cronin J. High-protein, low-fat, short-term diet results in less stress and fatigue than moderate-protein, moderate-fat diet during weight loss in male Weightlifters: A pilot study. Int J Sport Nutr Exerc Metab. 25: 163-170, 2015.

36. Hornsby W, Gentles J, MacDonald C, Mizuguchi S, Ramsey M, and Stone M. Maximum strength, rate of force development, jump height, and peak power alterations in Weightlifters across five months of training. Sports 5: 78, 2017.

37. James LP, Beckman EM, Kelly VG, and Haff GG. The neuromuscular qualities of higher and lower-level mixed martial arts competitors. Int J Sports Physiol Perform. 12(5): 612-620. 2017.

38. James LP, Roberts LA, Haff GG, Kelly VG, and Beckman EM. Validity and reliability of a portable isometric mid-thigh clean pull. J Strength Cond Res 31: 13781386, 2017.

39. Kawamori N, Rossi SJ, Justice BD, Haff EE, Pistilli EE, O'Bryant HS, Stone MH, and Haff GG. Peak force and rate of force development during isometric and dynamic mid-thigh clean pulls performed at various intensities. J Strength Cond Res. 20: 483491, 2006.

40. Khamoui AV, Brown LE, Nguyen D, Uribe BP, Coburn JW, Noffal GJ, and Tran T. Relationship between force-time and velocity-time characteristics of dynamic and isometric muscle actions. J Strength Cond Res 25: 198-204, 2011.

41. Kraska JM, Ramsey MW, Haff GG, Fethke N, Sands WA, Stone ME, and Stone MH. Relationship between strength characteristics and unweighted and weighted vertical jump height. Int J Sports Physiol Perform. 4: 461-473, 2009.

42. Leary BK, Statler J, Hopkins B, Fitzwater R, Kesling T, Lyon J, Phillips B, Bryner RW, Cormie P, and Haff GG. The relationship between isometric force-time curve characteristics and club head speed in recreational golfers. J Strength Cond Res 26: 2685-2697, 2012.

43. Maffiuletti NA, Aagaard P, Blazevich AJ, Folland J, Tillin N, and Duchateau J. Rate of force development: physiological and methodological considerations. Eur J Appl Physiol 116: 1091-1116, 2016.

44. Mangine GT, Hoffman JR, Wang R, Gonzalez AM, Townsend JR, Wells AJ, Jajtner AR, Beyer KS, Boone CH, Miramonti AA, LaMonica MB, Fukuda DH, Ratamess NA, and Stout JR. Resistance training intensity and volume affect changes in rate of force development in resistance-trained men. Eur J Applied Physiol. 116: 2367-2374, 2016.

45. McGuigan M and Winchester JB. The relationship between isometric and dynamic strength in collegiate football players. J Sports Sci Med 7: 101-105, 2008.

46. McGuigan MR, Newton MJ, Winchester JB, and Nelson AG. Relationship between isometric and dynamic strength in recreationally trained men. J Strength Cond Res 24: 2570-2573, 2010. 
47. McGuigan MR, Winchester JB, and Erickson T. The importance of isometric maximum strength In college wrestlers. J Sports Sci Med. 5: 108-113, 2006.

48. Moran J, Sandercock GRH, Ramírez-Campillo R, Wooller J-J, Logothetis S, Schoenmakers PPJM, and Parry DA. Maturation-related differences in adaptations to resistance training in young male swimmers. J Strength Cond Res. 32(1): 139-149. 2018.

49. Nuzzo JL, McBride JM, Cormie P, and McCaulley GO. Relationship between countermovement jump performance and multijoint isometric and dynamic tests of strength. J Strength Cond Res 22: 699-707, 2008.

50. Oranchuk DJ, Robinson TL, Switaj ZJ, and Drinkwater EJ. Comparison of the hang high-pull and loaded jump squat for the development of vertical jump and isometric force-time characteristics. J Strength Cond Res. Publish Ahead of Print, 2017.

51. Painter KB, Haff GG, Ramsey MW, McBride J, Triplett T, Sands WA, Lamont HS, Stone ME, and Stone MH. Strength gains: block versus daily undulating periodization weight training among track and field athletes. Int J Sports Physiol Perform 7: 161169, 2012.

52. Secomb JL, Farley OR, Lundgren L, Tran T, King A, Nimphius S, and Sheppard J. Associations between the performance of scoring manouvres and lower-body strength and power in elite surfers. Int J Sports Sci Coach 10: 911-918, 2015.

53. Secomb JL, Lundgren LE, Farley OR, Tran TT, Nimphius S, and Sheppard JM. Relationships between lower-body muscle structure and lower-body strength, power, and muscle-tendon complex stiffness. J Strength Cond Res 29: 2221-2228, 2015.

54. Secomb JL, Nimphius S, Farley OR, Lundgren L, Tran T, and Sheppard J. Relationships between lower-body muscle structure and, lower-body strength, explosiveness and eccentric leg stiffness in adolescent athletes. J Sports Sci Med 14: 691-697, 2015.

55. Seitz LB, Reyes A, Tran TT, de Villarreal ES, and Haff GG. Increases in lower-body strength transfer positively to sprint performance: a systematic review with metaanalysis. Sports Med 44 1693-1702, 2014.

56. Sheppard J, Chapman D, and Taylor K. An evaluation of a strength qulities assessment method for the lower body. JASC 19: 4-10, 2011.

57. Sjokvist J, Sandbakk O, Willis SJ, Andersson E, and Holmberg HC. The effect of incline on sprint and bounding performance in cross-country skiers. J Sports Med Phys Fitness 55: 405-414, 2015.

58. Spiteri T, Newton RU, and Nimphius S. Neuromuscular strategies contributing to faster multidirectional agility performance. J Electromyogr Kinesiol 25: 629-636, 2015.

59. Spiteri T, Nimphius S, Hart NH, Specos C, Sheppard JM, and Newton RU. Contribution of strength characteristics to change of direction and agility performance in female basketball athletes. J Strength Cond Res 28: 2415-2423, 2014.

60. Stone MH, Sands WA, Carlock J, Callan S, Dickie D, Daigle K, Cotton J, Smith SL, and Hartman M. The importance of isometric maximum strength and peak rate-offorce development in sprint cycling. J Strength Cond Res 18: 878-884, 2004.

61. Street G, McMillan S, Board W, Rasmussen M, and Heneghan JM. Sources of error in determining countermovement jump height with the impulse method. $J$ Appl Biomech 17: 43-54, 2001.

62. Suchomel TJ, Lamont HS, and Moir GL. Understanding vertical jump potentiation: a deterministic model. Sports Med 46: 809-828, 2016.

63. Suchomel TJ, Nimphius S, and Stone MH. The importance of muscular strength in athletic performance. Sports Med 46: 1419-1449, 2016. 
64. Thomas C, Comfort P, Chiang CY, and Jones PA. Relationship between isometric mid-thigh pull variables and sprint and change of direction performance in collegiate athletes. J Trainology 4: 6-10, 2015.

65. Thomas C, Dos'Santos T, Comfort P, and Jones P. Between-session reliability of common strength- and power-related measures in adolescent athletes. Sports 5: 15, 2017.

66. Thomas C, Jones PA, and Comfort P. Reliability of the dynamic strength index in collegiate athletes. Int J Sports Physiol Perform 10: 542-545, 2015.

67. Thomas C, Jones PA, Rothwell J, Chiang CY, and Comfort P. An Investigation into the relationship between maximum isometric strength and vertical jump performance. J Strength Cond Res 29: 2176-2185, 2015.

68. Tran TT, Lundgren L, Secomb J, Farley ORL, Haff GG, Seitz LB, Newton RU, Nimphius S, and Sheppard JM. Comparison of physical capacities between nonselected and selected elite male competitive surfers for the national junior team. Int J Sports Physiol Perform 10: 178-182, 2015.

69. Wang R, Hoffman JR, Tanigawa S, Miramonti AA, La Monica MB, Beyer KS, Church DD, Fukuda DH, and Stout JR. Isometric mid-thigh pull correlates with strength, sprint, and agility performance in collegiate rugby union players. J Strength Cond Res 30: 3051-3056, 2016.

70. Welch N, Moran K, Antony J, Richter C, Marshall B, Coyle J, Falvey E, and Franklyn-Miller A. The effects of a free-weight-based resistance training intervention on pain, squat biomechanics and MRI-defined lumbar fat infiltration and functional cross-sectional area in those with chronic low back. BMJ Open Sport Exerc Med 1, 2015.

71. West DJ, Owen NJ, Jones MR, Bracken RM, Cook CJ, Cunningham DJ, Shearer DA, Finn CV, Newton RU, Crewther BT, and Kilduff LP. Relationships between forcetime characteristics of the isometric midthigh pull and dynamic performance in professional rugby league players. J Strength Cond Res 25: 3070-3075, 2011.

72. Whittington J, Schoen E, Labounty LL, Hamdy R, Ramsey MW, Stone ME, Sands WA, Haff GG, and Stone MH. Bone mineral density and content of collegiate throwers: influence of maximum strength. J Sports Med Phys Fitness 49: 464-473, 2009.

73. Winchester J, McGuigan MR, Nelson AG, and Newton M. The relationship between isometric and dynamic strength in college aged males. J Strength Cond Res 24: 1, 2010.

74. Winchester JB, McBride JM, Maher MA, Mikat RP, Allen BK, Kline DE, and McGuigan MR. Eight weeks of ballistic exercise improves power independently of changes in strength and muscle fiber type expression. J Strength Cond Res 22: 17281734, 2008.

\section{Figure and Table Legends:}

Figure 1: Relationships between isometric mid-thigh pull peak force and performance in other tasks

Figure 2: Correct posture for the isometric mid-thigh pull, illustrating an upright trunk, replicating the start position of the second pull of the clean

Figure 3: Standardized warm-up procedure 
Figure 4: Standardized isometric mid-thigh pull testing procedure

568 Figure 5: Examples of acceptable and unacceptable isometric mid-thigh pull force-time traces

Table 1: Relationships between peak force and performance in other activities

572

573 Table 2: Relationships between time specific force and performance in other activities

575 Table 3: Relationships between rate of force development and performance in other activities

Table 4: Relationships between time specific impulse and performance in other activities 
Table 1: Relationships between peak force and performance in other activities

\begin{tabular}{|c|c|c|c|c|c|c|}
\hline Author(s) & Subjects & 1RM & Sprint & Jump & Change of Direction & Other \\
\hline Haff et al. (39) & $\begin{array}{l}8 \text { trained }(>2 \text { years }) \\
\text { men } \\
1 \mathrm{RM} \mathrm{PC}=1 \cdot 21 \mathrm{~kg} \cdot \mathrm{kg}^{-1}\end{array}$ & & & SJ PF: $r=0.76$ & & $\begin{array}{l}\text { Force during dynamic MTP } \\
90 \% 1 \mathrm{RM}: r=0.77 \\
100 \% 1 \mathrm{RM}: r=0.80\end{array}$ \\
\hline Stone et al. 60 & $\begin{array}{l}30 \text { competitive sprint } \\
\text { cyclists }\end{array}$ & & & $\begin{array}{l}\text { CMJ height: } r=0.59 \\
\text { CMJ PP: } r=0.79 \\
\text { SJ height: } r=0.51 \\
\text { SJ PP: } r=0.78\end{array}$ & & $\begin{array}{l}\text { Absolute PF \& Sprint } \\
\text { cycling performances: } r= \\
0.49-0.55 \\
\text { Relative PF \& Sprint cycling } \\
\text { performances: } r=0.45-0.60 \\
A S \text { PF \& Sprint cycling } \\
\text { performances: } r=0.45-0.58\end{array}$ \\
\hline Haff et al. (30) & $\begin{array}{lcc}6 & \text { elite } & \text { women } \\
\text { weightlifters } & \end{array}$ & Snatch: $r=0.93$ & & $\begin{array}{l}\text { CMJ PP: } r=0.88 \\
\text { SJ PP: } r=0.92\end{array}$ & & \\
\hline $\begin{array}{l}\text { Kawamori et al. } \\
(39)\end{array}$ & $\begin{array}{l}8 \text { male collegiate } \\
\text { weightlifters } \\
1 \mathrm{RM} \mathrm{PC}=1.39 \mathrm{~kg} \cdot \mathrm{kg}^{-1}\end{array}$ & & & $\begin{array}{l}\text { CMJ PF: } r=0.87 \\
\text { CMJ PRFD: } r=0.85 \\
\text { CMJ PP: } r=0.95\end{array}$ & & $\begin{array}{l}\text { Force during dynamic MTP } \\
90 \% 1 \mathrm{RM}: r=0.82\end{array}$ \\
\hline $\begin{array}{l}\text { McGuigan et al. } \\
(47)\end{array}$ & $\begin{array}{l}8 \text { division III collegiate } \\
\text { wrestlers }\end{array}$ & $\begin{array}{l}\text { PC: } r=0.97 \\
\text { Squat: } r=0.96 \\
\text { BP: } r=0.73\end{array}$ & & & & \\
\hline $\begin{array}{ll}\text { McGuigan } & \& \\
\text { Winchester (45) } & \end{array}$ & $\begin{array}{l}22 \text { college football } \\
\text { players } \\
1 \mathrm{RM} \mathrm{PC}=1.11 \mathrm{~kg} \cdot \mathrm{kg}^{-1} \\
1 \mathrm{RM} \text { Squat }=1.75 \\
\mathrm{~kg} \cdot \mathrm{kg}^{-1}\end{array}$ & $\begin{array}{l}\text { PC, Squat, BP: r } \\
=0.61-0.72^{*}\end{array}$ & & & & \\
\hline Nuzzo et al. (49) & $\begin{array}{l}12 \text { division I collegiate } \\
\text { athletes } \\
1 \mathrm{RM} \mathrm{PC}=1.28 \mathrm{~kg} \cdot \mathrm{kg}^{-1} \\
1 \mathrm{RM} \text { Squat }=1.91 \\
\mathrm{~kg} \cdot \mathrm{kg}^{-1}\end{array}$ & $P C: r=0.74$ & & $\begin{array}{l}\text { CMJ PP: } r=0.75 \\
\text { Relative PF \& CMJ } \\
\text { height: } r=0.59\end{array}$ & & \\
\hline Kraska et al. (41) & $\begin{array}{l}41 \text { female and } 22 \text { male } \\
\text { collegiate athletes }\end{array}$ & & & $\begin{array}{l}\text { SJ: } r=0.40 \\
\text { SJ20: } r=0.55 \\
\text { CMJ: } r=0.36 \\
\text { CMJ20: } r=0.55 \\
\text { AS PF: }\end{array}$ & & \\
\hline
\end{tabular}




\begin{tabular}{|c|c|c|c|c|c|c|}
\hline & & & & $\begin{array}{l}\text { SJ: } r=0.47 \\
\text { SJ20: } r=0.52 \\
\text { CMJ: } r=0.41 \\
\text { CMJ20: } r=0.52\end{array}$ & & \\
\hline $\begin{array}{l}\text { Whittington et al. } \\
\text { (72) }\end{array}$ & $\begin{array}{l}7 \text { NCAA Division I } \\
\text { track and field athletes }\end{array}$ & & & & & $\begin{array}{l}\text { Ball throw distance } \\
\text { PF: } r=0.89 \\
A S P F: r=0.91\end{array}$ \\
\hline $\begin{array}{l}\text { McGuigan et al. } \\
(46)\end{array}$ & $\begin{array}{l}26 \text { recreationally } \\
\text { trained men } \\
1 \mathrm{RM} \text { Squat }=1.30 \\
{\mathrm{~kg} \cdot \mathrm{kg}^{-1}}\end{array}$ & $\begin{array}{l}\text { Squat: } r=0.97 \\
\text { BP: } r=0.99\end{array}$ & & CMJ height: $r=0.72$ & & \\
\hline Khamoui et al. (40) & $\begin{array}{l}19 \text { recreationally } \\
\text { trained men }\end{array}$ & & & $\begin{array}{l}\text { Relative PF \& CMJ } \\
\text { height: } r=0.61\end{array}$ & & $\begin{array}{l}\text { Relative PF \& high pull PV: } \\
r=-0.60\end{array}$ \\
\hline West et al. (71) & $\begin{array}{l}39 \text { professional rugby } \\
\text { league players }\end{array}$ & & $\begin{array}{l}\text { Relative } P F \& \\
10 \quad \mathrm{~m} \text { sprint } \\
\text { time: } r=0.37\end{array}$ & $\begin{array}{l}\text { Relative PF \& CMJ } \\
\text { height: } r=0.45\end{array}$ & & \\
\hline Spiteri et al. (59) & $\begin{array}{l}12 \text { competitive female } \\
\text { basketball players }\end{array}$ & $\begin{array}{l}\text { IMTP relative } \\
\text { PF, back squat: } \\
r=0.81\end{array}$ & & & $\begin{array}{l}\text { T-Test: } r=-0.85 \\
505 \text { COD }=-0.79\end{array}$ & \\
\hline $\begin{array}{l}\text { Winchester et al. } \\
(73)\end{array}$ & $\begin{array}{l}26 \quad \text { recreationally } \\
\text { trained men } \\
1 \mathrm{RM} \text { Squat }=1.30 \\
\mathrm{~kg} \cdot \mathrm{kg}^{-1}\end{array}$ & $\begin{array}{l}\text { Squat: } r=0.97 \\
\text { BP: } r=0.99\end{array}$ & & CMJ height: $r=0.72$ & & \\
\hline Secomb et al. (53) & 15 elite surfers & & & $\begin{array}{l}\text { CMJ height: } r=0.65 \\
\text { SJ height: } r=0.58\end{array}$ & & \\
\hline Beckham et al. (7) & $\begin{array}{l}12 \text { collegiate-national } \\
\text { level weightlifters }\end{array}$ & $\begin{array}{l}\text { Snatch: } r=0.83 \\
\text { Clean \& Jerk: } r \\
=0.84 \\
\text { Total: } r=0.84\end{array}$ & & & & \\
\hline Thomas et al. (64) & $\begin{array}{|ll|}14 \text { collegiate team } \\
\text { sport athletes }\end{array}$ & & $\begin{array}{l}5 m: r=-0.57 \\
20 m: r=-0.69\end{array}$ & & 505mod: $r=-0.57$ & \\
\hline Thomas et al. (67) & $\begin{array}{|ll|}22 \text { collegiate team } \\
\text { sport athletes }\end{array}$ & & & CMJ PF: $r=0.45$ & & \\
\hline Wang et al. (69) & $\begin{array}{l}15 \text { collegiate rugby } \\
\text { players }\end{array}$ & Squat: $r=0.866$ & & & & \\
\hline \multicolumn{7}{|c|}{$\begin{array}{l}\text { PC = Power Clean; BP = Bench Press; SJ = Squat Jump; CMJ = Countermovement Jump; } 505 \text { mod = Modified } 505 \text { change of direction } \\
\text { PF = Peak Force; PP = Peak Power: PV = Peak Velocity; PRFD = Peak Rate of Force Development; } A S=\text { Allometrically Scaled } \\
\text { *Individual correlations not reported }\end{array}$} \\
\hline
\end{tabular}


Table 2: Relationships between time specific force and performance in other activities

\begin{tabular}{|c|c|c|c|c|c|}
\hline Author(s) & Subjects & 1RM & Sprint & Jump & Other \\
\hline Kraska et al. (41) & $\begin{array}{l}41 \text { female and } 22 \\
\text { male collegiate } \\
\text { athletes }\end{array}$ & & & $\begin{array}{l}\text { PF50 } \\
\text { SJ: } r=0.33 \\
\text { SJ20: } r=0.52 \\
\text { CMJ: } r=0.27 \\
\text { CMJ20: } r=0.50 \\
\text { AS PF50: } \\
\text { SJ: } r=0.33 \\
\text { SJ20: } r=0.48 \\
\text { CMJ20: } r=0.45 \\
\text { PF90 } \\
\text { SJ20: } r=0.37 \\
\text { CMJ20: } r=0.33 \\
\text { AS PF90: } \\
\text { CMJ20: } r=0.48 \\
\text { PF250 } \\
\text { SJ: } r=0.39 \\
\text { SJ20: } r=0.56 \\
\text { CMJ: } r=0.34 \\
\text { CMJ20: } r=0.54 \\
\text { AS PF250 } \\
\text { SJ: } r=0.42 \\
\text { SJ20: } r=0.51 \\
\text { CMJ: } r=0.34 \\
\text { CMJ20: } r=0.48\end{array}$ & \\
\hline Beckham et al. (7) & $\begin{array}{lr}12 & \text { collegiate- } \\
\text { national } & \text { level } \\
\text { weightlifters }\end{array}$ & $\begin{array}{l}\text { F100 } \\
\text { Snatch: } r=0.65 \\
\text { Clean \& Jerk: } r=0.64 \\
\text { Combined Total: } r=0.65 \\
\text { F150 } \\
\text { Snatch: } r=0.64 \\
\text { Clean \& Jerk: } r=0.61 \\
\text { Combined Total: } r=0.62 \\
\text { F200 } \\
\text { Snatch: } r=0.73 \\
\text { Clean \& Jerk: } r=0.71\end{array}$ & & & \\
\hline
\end{tabular}




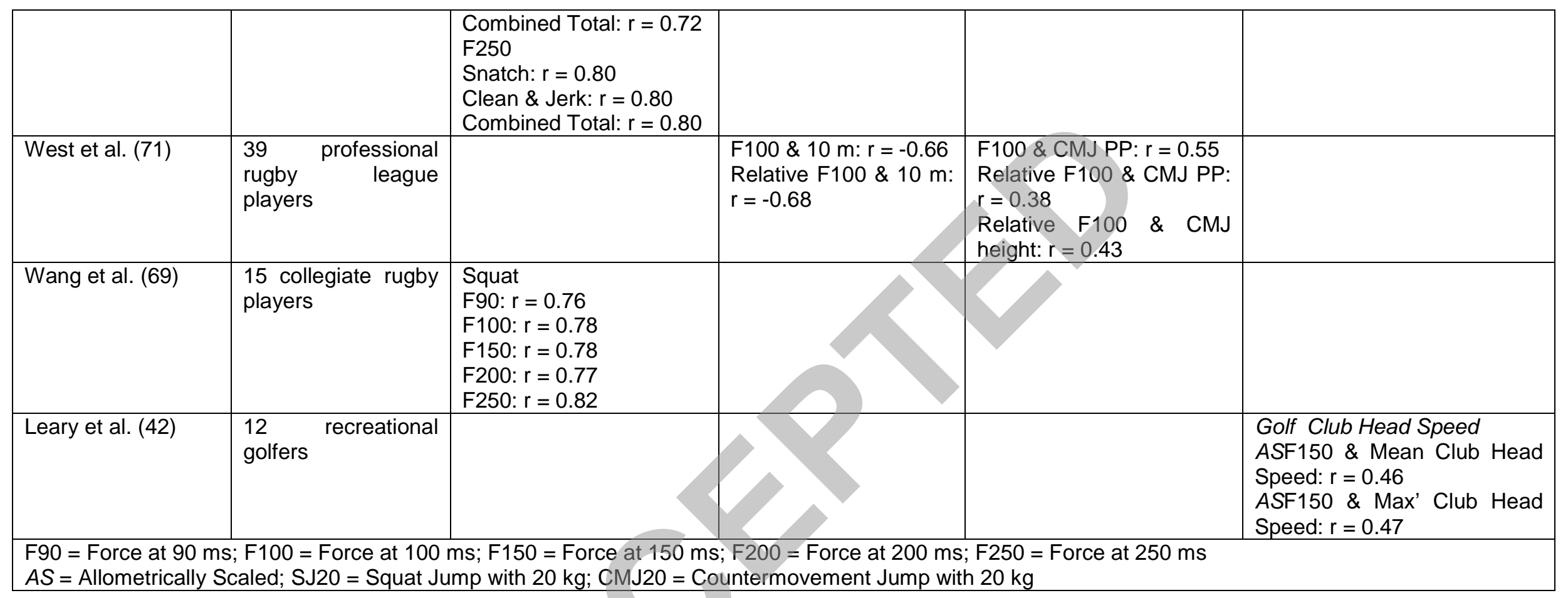


Table 3: Relationships between RFD and performance in other activities

\begin{tabular}{|c|c|c|c|c|c|c|}
\hline Author(s) & Subjects & 1RM & Sprint & Jump & Change of Direction & Other \\
\hline Haff et al. (33) & $\begin{array}{l}8 \quad \text { trained } \quad(>2 \\
\text { years }) \text { men } \\
1 \mathrm{RM} P C=1.21 \\
\mathrm{~kg} \cdot \mathrm{kg}^{-1}\end{array}$ & & & $\begin{array}{l}\text { PRFD } \\
\text { SJ Power: } r=0.76 \\
\text { SJ Height: } r=0.82\end{array}$ & & $\begin{array}{l}\text { RFD during dynamic MTP } \\
80 \% 1 \mathrm{RM}: r=0.84 \\
90 \% 1 \mathrm{RM}: r=0.88 \\
100 \% 1 \mathrm{RM}: r=0.84\end{array}$ \\
\hline Haff et al. (30) & $\begin{array}{l}6 \text { elite women } \\
\text { weightlifters }\end{array}$ & $\begin{array}{l}\text { PRFD } \\
\text { Snatch: } r=0.79 \\
\text { Combined Total: } r= \\
0.80\end{array}$ & & $\begin{array}{l}\text { PRFD } \\
\text { CMJ P } \\
\text { SJ PP: }\end{array}$ & & \\
\hline $\begin{array}{l}\text { McGuigan et al. } \\
(47)\end{array}$ & $\begin{array}{l}8 \text { division III } \\
\text { collegiate } \\
\text { wrestlers }\end{array}$ & & & & & $\begin{array}{l}\text { PRFD \& Coaching Ranking: } \\
r=0.62\end{array}$ \\
\hline $\begin{array}{l}\text { Kawamori et al. } \\
(39)\end{array}$ & $\begin{array}{l}8 \text { male collegiate } \\
\text { weightlifters } \\
1 \mathrm{RM} \mathrm{PC}=1.39 \\
\mathrm{~kg} \cdot \mathrm{kg}^{-1}\end{array}$ & & & & & $\begin{array}{l}\text { Force during dynamic MTP } \\
90 \% 1 \mathrm{RM}: r=0.69 \\
120 \% 1 \mathrm{RM}: r=0.74\end{array}$ \\
\hline Nuzzo et al. (49) & $\begin{array}{l}12 \text { division } \\
\text { collegiate athletes } \\
1 \mathrm{RM} \mathrm{PC}=1.28 \\
\mathrm{~kg}^{\circ} \mathrm{kg}^{-1} \\
1 \mathrm{RM} \mathrm{Squat}^{-1.91} \\
\mathrm{~kg}^{-1} \mathrm{~kg}^{-1}\end{array}$ & & & $\begin{array}{l}\text { PRFD } \\
\text { CMJ PP: } r=0.65\end{array}$ & & \\
\hline Kraska et al. (41) & $\begin{array}{l}41 \text { female and } 22 \\
\text { male collegiate } \\
\text { athletes }\end{array}$ & & & $\begin{array}{l}\text { PRFD } \\
\text { SJ: } r=0.48 \\
\text { SJ20: } r=0.66 \\
\text { CMJ: } r=0.43 \\
\text { CMJ20: } r=0.62\end{array}$ & & \\
\hline $\begin{array}{l}\text { Whittington et al. } \\
\text { (72) }\end{array}$ & $\begin{array}{l}7 \text { NCAA Division I } \\
\text { track and field } \\
\text { athletes }\end{array}$ & & & & & Ball throw distance: $r=0.78$ \\
\hline Khamoui et al. (40) & $\begin{array}{l}19 \text { recreationally } \\
\text { trained men }\end{array}$ & $\gamma$ & & & & $\begin{array}{l}\text { RFD50 \& high pull PV: } r= \\
0.56 \\
\text { RFD100 \& high pull PV: } r= \\
0.56\end{array}$ \\
\hline West et al. (71) & $\begin{array}{l}39 \text { professional } \\
\text { rugby league }\end{array}$ & & $\begin{array}{l}\text { PRFD } \\
10 \mathrm{~m}: \mathrm{r}=-0.66\end{array}$ & $\begin{array}{l}\text { PRFD } \\
\text { CMJ height: } r=\end{array}$ & & \\
\hline
\end{tabular}




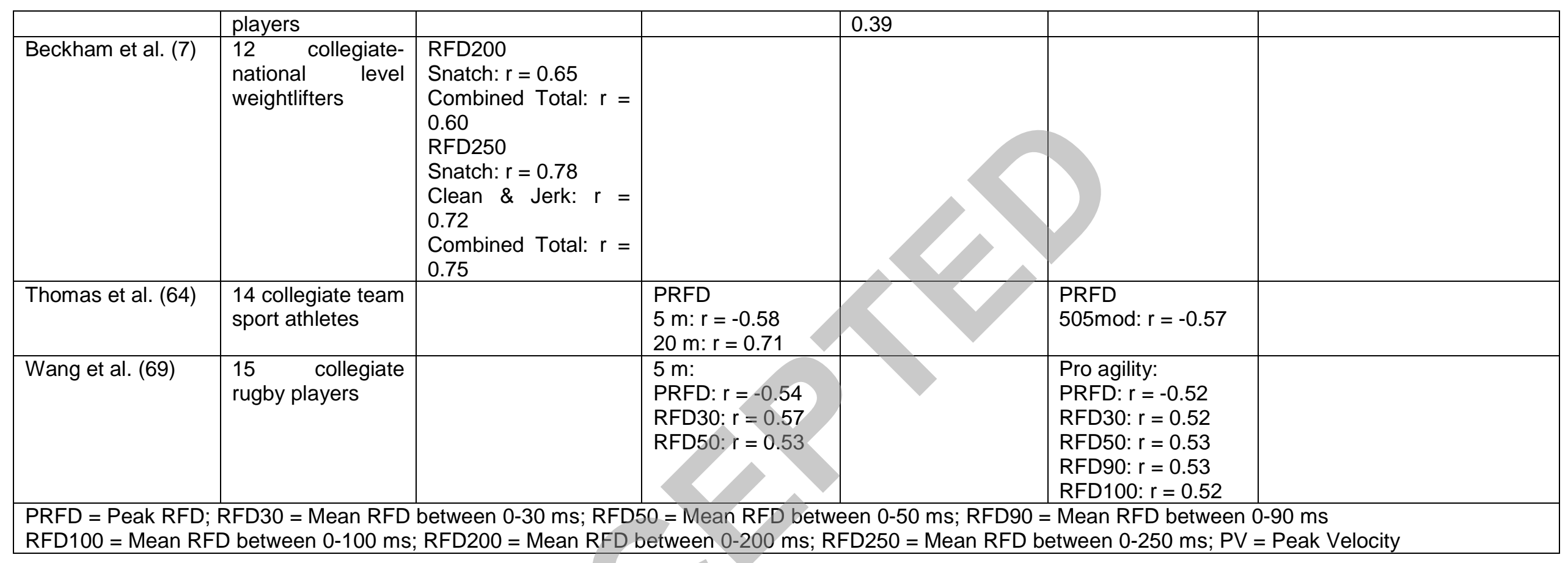


Table 4: Relationships between time specific impulse and performance in other activities

\begin{tabular}{|c|c|c|c|c|}
\hline Author(s) & Subjects & Sprint & Jump & Change of Direction \\
\hline Thomas et al. (64) & $\begin{array}{l}14 \text { collegiate team } \\
\text { sport athletes }\end{array}$ & $\begin{array}{l}\text { Imp100 } \\
5 \mathrm{~m}: r=-0.71 \\
20 \mathrm{~m}: r=0.75 \\
\text { Imp300 } \\
5 \mathrm{~m}: \mathrm{r}=-0.74 \\
20 \mathrm{~m}: r=0.78\end{array}$ & & $\begin{array}{l}\text { Imp100, 505mod: } r=-0.58 \\
\text { Imp300, 505mod: } r=-0.62\end{array}$ \\
\hline Thomas et al. (67) & $\begin{array}{l}22 \text { collegiate team } \\
\text { sport athletes }\end{array}$ & & $\begin{array}{l}\text { Imp100 } \\
\text { SJ PF: } r=0.57 \\
\text { SJ PP: } r=0.60 \\
\text { CMJ PF: } r=0.64 \\
\text { CMJ PP: } r=0.51 \\
\text { Imp200 } \\
\text { SJ PF: } r=0.56 \\
\text { SJ PP: } r=0.59 \\
\text { CMJ PF: } r=0.63 \\
\text { CMJ PP: } r=0.50 \\
\text { Imp300 } \\
\text { SJPF: } r=0.58 \\
\text { SJ PP: } r=0.60 \\
\text { CMJ PF: } r=0.63 \\
\text { CMJ PP: } r=0.49\end{array}$ & \\
\hline
\end{tabular}


Table 5: Reported Testing and Data Analysis Procedures

\begin{tabular}{|c|c|c|c|c|c|c|c|}
\hline Author(s) & Knee Angle & Hip Angle & $\begin{array}{l}\text { Sampling } \\
\text { Frequency }\end{array}$ & $\begin{array}{c}\text { Onset } \\
\text { Threshold }\end{array}$ & Scaling & $\begin{array}{l}\text { Smoothing \& } \\
\text { Filtering }\end{array}$ & RFD Calculation \\
\hline Haff et al. (33) & $144 \pm 5^{\circ}$ & $145 \pm 3^{\circ}$ & $500 \mathrm{~Hz}$ & --- & Net Force & --- & $\begin{array}{l}\text { PRFD (2 ms } \\
\text { window) }\end{array}$ \\
\hline Stone et al. (60) & $140-145^{\circ}$ & --- & $600 \mathrm{~Hz}$ & - & Net & --- & $\begin{array}{l}\text { PRFD (1.7 ms } \\
\text { window) }\end{array}$ \\
\hline Haff et al. (30) & $127-145^{\circ}$ * & --- & $600 \mathrm{~Hz}$ & & Net Force & --- & $\begin{array}{l}\text { PRFD (1.7 ms } \\
\text { window) }\end{array}$ \\
\hline $\begin{array}{l}\text { McGuigan et al. } \\
(47)\end{array}$ & $130^{\circ}$ & --- & $500 \mathrm{~Hz}$ & - & Absolute & -- & $\begin{array}{l}\text { PRFD (2 ms } \\
\text { window) }\end{array}$ \\
\hline $\begin{array}{l}\text { Kawamori et al. } \\
(39)\end{array}$ & $141 \pm 10^{\circ}$ & $124 \pm 11^{\circ}$ & $500 \mathrm{H}$ & -- & -- & --- & $\begin{array}{l}\text { PRFD (2 ms } \\
\text { window) }\end{array}$ \\
\hline Haff et al. (31) & $127-145^{\circ}$ * & --- & & --- & Net Force & --- & $\begin{array}{l}\text { PRFD (1.7 ms } \\
\text { window) }\end{array}$ \\
\hline Nuzzo et al. (49) & $140^{\circ}$ & --- & $1000 \mathrm{~Hz}$ & --- & Ratio & --- & Mean RFD \\
\hline $\begin{array}{l}\text { Winchester et al. } \\
(74)\end{array}$ & $130^{\circ}$ & -- & & --- & Net & --- & --- \\
\hline $\begin{array}{l}\text { Winchester et al. } \\
\text { (73) \# }\end{array}$ & --- & - & & --- & --- & --- & --- \\
\hline $\begin{array}{l}\text { McGuigan \& } \\
\text { Winchester (45) }\end{array}$ & $130^{\circ}$ & -- & $960 \mathrm{~Hz}$ & --- & --- & --- & $\begin{array}{l}\text { Assumed peak } \\
\text { due to the } \\
\text { values }\end{array}$ \\
\hline Kraska et al. (41) & $120-135^{\circ}$ & $\begin{array}{c}170-175^{\circ} \\
¥ \text { In line with } \\
\text { Haff et al (1997) }\end{array}$ & $1000 \mathrm{~Hz}$ & -- & $\begin{array}{c}\text { Absolute \& } \\
\text { AS }\end{array}$ & --- & $\begin{array}{l}\text { Assumed peak } \\
\text { due to the } \\
\text { values }\end{array}$ \\
\hline $\begin{array}{l}\text { Whittington et al. } \\
(72)\end{array}$ & $\begin{array}{c}120-135^{\circ} \\
\text { 'Self-selected' }\end{array}$ & $\begin{array}{c}170-175^{\circ} \\
\text { 'Self-selected' }\end{array}$ & $1000 \mathrm{~Hz}$ & --- & --- & --- & $\begin{array}{l}\text { PRFD (1 ms } \\
\text { window) }\end{array}$ \\
\hline $\begin{array}{l}\text { McGuigan et al. } \\
(46)\end{array}$ & $130^{\circ}$ & --- & $960 \mathrm{~Hz}$ & --- & Assumed & --- & Assumed mean \\
\hline
\end{tabular}




\begin{tabular}{|c|c|c|c|c|c|c|c|}
\hline & & & & & $\begin{array}{l}\text { Net due to } \\
\text { the values }\end{array}$ & & $\begin{array}{l}\text { due to the } \\
\text { values }\end{array}$ \\
\hline $\begin{array}{l}\text { Crewther et al. } \\
(16)\end{array}$ & $\begin{array}{c}120-130^{\circ} \\
¥ \text { In line with } \\
\text { Haff et al } \\
\text { (2005), Stone } \\
\text { et al (2004) }\end{array}$ & --- & $1000 \mathrm{~Hz}$ & & Net & $\begin{array}{l}\text { Dual pass } \\
\text { Butterworth } \\
\text { filter (low } \\
\text { pass, } 20 \mathrm{~Hz} \\
\text { cut-off) } \\
\end{array}$ & $\begin{array}{l}\text { PRFD (1 ms } \\
\text { window) }\end{array}$ \\
\hline Beckham et al. (6) & $\begin{array}{c}\text { ¥ In line with } \\
\text { Haff et al. } \\
\text { (1997) and } \\
\text { Kraska et al. } \\
\text { (2009) }\end{array}$ & $\begin{array}{c}\text { In line with } \\
\text { Haff et al. } \\
(1997) \text { and } \\
\text { Kraska et al. } \\
(2009)\end{array}$ & $1000 \mathrm{~Hz}$ & & $\begin{array}{l}\text { Absolute \& } \\
\text { AS }\end{array}$ & $\begin{array}{c}4^{\text {th }} \text { Order } \\
\text { Butterworth } \\
\text { low pass filter } \\
100 \mathrm{~Hz}\end{array}$ & Not included \\
\hline Beckham et al. (7) & $120-135^{\circ}$ & $175^{\circ}$ & 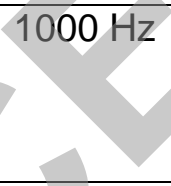 & -- & $\begin{array}{l}\text { Absolute, } \\
\text { Ratio \& AS }\end{array}$ & $\begin{array}{c}4^{\text {th }} \text { Order } \\
\text { Butterworth } \\
\text { low pass filter } \\
100 \mathrm{~Hz} \\
\end{array}$ & $\begin{array}{l}\text { Mean \& PRFD } \\
\text { (1 ms window) }\end{array}$ \\
\hline Comfort et al. (11) & $\begin{array}{c}120^{\circ}, 130^{\circ} \\
140^{\circ}, 150^{\circ} \& \\
\text { Self-selected } \\
\left(133 \pm 3^{\circ}\right)\end{array}$ & $\begin{array}{c}125^{\circ}, 145^{\circ} \& \\
\text { Self-selected } \\
\left(138 \pm 4^{\circ}\right)\end{array}$ & $600 \mathrm{~Hz}$ & $40 \mathrm{~N}$ & Absolute & --- & $\begin{array}{l}\text { PRFD (1.7 ms } \\
\text { window) }\end{array}$ \\
\hline Thomas et al. (64) & Self-selected & Self-selected & $600 \mathrm{~Hz}$ & --- & Absolute & $\begin{array}{c}4^{\text {th }} \text { Order } \\
\text { Butterworth } \\
\text { low pass filter } \\
16 \mathrm{~Hz}\end{array}$ & $\begin{array}{l}\text { PRFD (1.7 ms } \\
\text { window) }\end{array}$ \\
\hline Thomas et al. (67) & Self-selected & Self-selected & $600 \mathrm{~Hz}$ & -- & $\begin{array}{l}\text { Absolute \& } \\
\text { Relative }\end{array}$ & $\begin{array}{c}4^{\text {th }} \text { Order } \\
\text { Butterworth } \\
\text { low pass filter } \\
16 \mathrm{~Hz}\end{array}$ & $\begin{array}{l}\text { PRFD (1.7 ms } \\
\text { window) }\end{array}$ \\
\hline
\end{tabular}




\begin{tabular}{|c|c|c|c|c|c|c|c|}
\hline Thomas et al. (66) & Self-selected & Self-selected & $600 \mathrm{~Hz}$ & --- & Absolute & $\begin{array}{c}4^{\text {th }} \text { Order } \\
\text { Butterworth } \\
\text { low pass filter } \\
16 \mathrm{~Hz}\end{array}$ & Not included \\
\hline Haff et al. (32) & $140.0 \pm 6.6^{\circ}$ & $137.6 \pm 12.9^{\circ}$ & $1000 \mathrm{~Hz}$ & --- & Net & $\begin{array}{l}\text { Rectangular } \\
\text { smoothing } \\
\text { with a moving } \\
\text { half-width of } \\
12\end{array}$ & $\begin{array}{l}\text { PRFD (20 ms } \\
\text { window) } \\
\text { RFD }_{30,50,90,100} \\
150,200,250\end{array}$ \\
\hline $\begin{array}{l}\text { Secomb, et al. } \\
(52)\end{array}$ & $125-140^{\circ}$ & --- & $600 \mathrm{~Hz}$ & & Absolute & --- & Not included \\
\hline Secomb et al. (53) & $125-140^{\circ}$ & --- & $600 \mathrm{~Hz}$ & & $\begin{array}{c}\text { Absolute } \\
\text { and } \\
\text { Relative }\end{array}$ & --- & Not included \\
\hline Secomb et al. (54) & $\begin{array}{c}--- \\
\text { Stated similar } \\
\text { to Haff et al. } \\
(2005)\end{array}$ & $\begin{array}{c}\text {--- } \\
\text { Stated similar to } \\
\text { Haff et al. } \\
(2005)\end{array}$ & & +-- & $\begin{array}{c}\text { Absolute } \\
\text { and } \\
\text { Relative }\end{array}$ & --- & Not included \\
\hline Tran et al. (68) & $\begin{array}{c}\text { Stated similar } \\
\text { to Haff et al. } \\
(1997)\end{array}$ & $\begin{array}{c}\text { Stated similar to } \\
\text { Haff et al. } \\
(1997)\end{array}$ & & --- & $\begin{array}{c}\text { Absolute } \\
\text { and } \\
\text { Relative } \\
\text { (Assumed } \\
\text { Net due to } \\
\text { the values) }\end{array}$ & $\begin{array}{c}4^{\text {th }} \text { Order } \\
\text { Butterworth } \\
\text { low pass filter } \\
10 \mathrm{~Hz}\end{array}$ & \\
\hline Spiteri et al. (58) & $140^{\circ}$ & $140^{\circ}$ & $2000 \mathrm{~Hz}$ & --- & Relative & --- & $\mathrm{RFD}_{30,50,90,100}$ \\
\hline Sjokvist et al. (57) & \multicolumn{4}{|c|}{--- States in line with Stone et al. (2004) } & $\begin{array}{c}\text { Absolute } \\
\text { and } \\
\text { Relative }\end{array}$ & --- & Not included \\
\hline Welch et al. (70) & \multicolumn{4}{|c|}{ No specific detail provided other than bar positioned at mid-thigh } & Relative & --- & Not included \\
\hline Wang et al. (69) & Self-selected & Self-selected & $1000 \mathrm{~Hz}$ & --- & Net & --- & $\begin{array}{c}\text { PRFD (20 ms } \\
\text { window) } \\
\text { RFD }_{30,50,90,100} \\
150,200,250\end{array}$ \\
\hline Mangine et al. & Self-selected & Self-selected & $1000 \mathrm{~Hz}$ & --- & Net & --- & PRFD $(20 \mathrm{~ms}$ \\
\hline
\end{tabular}




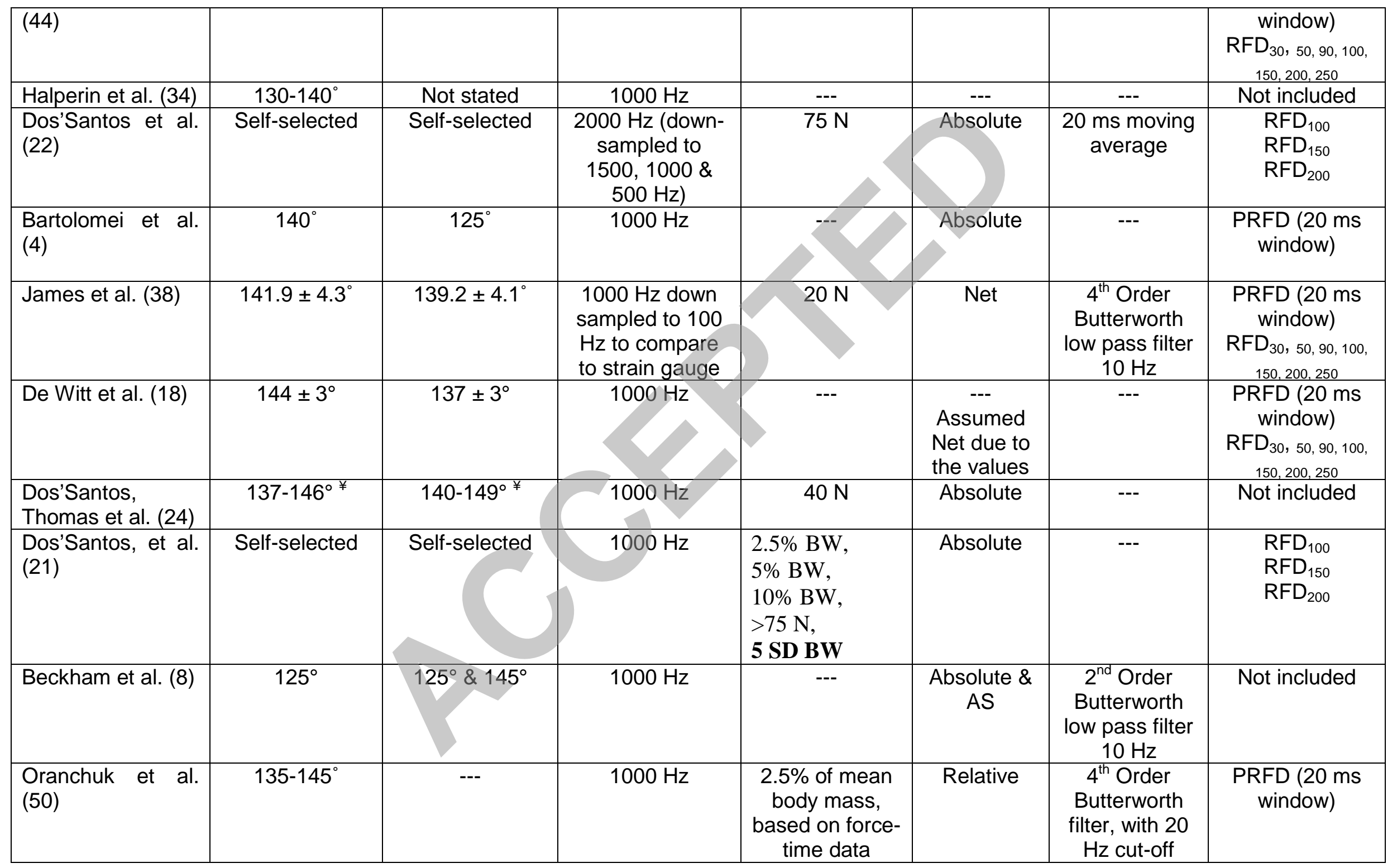




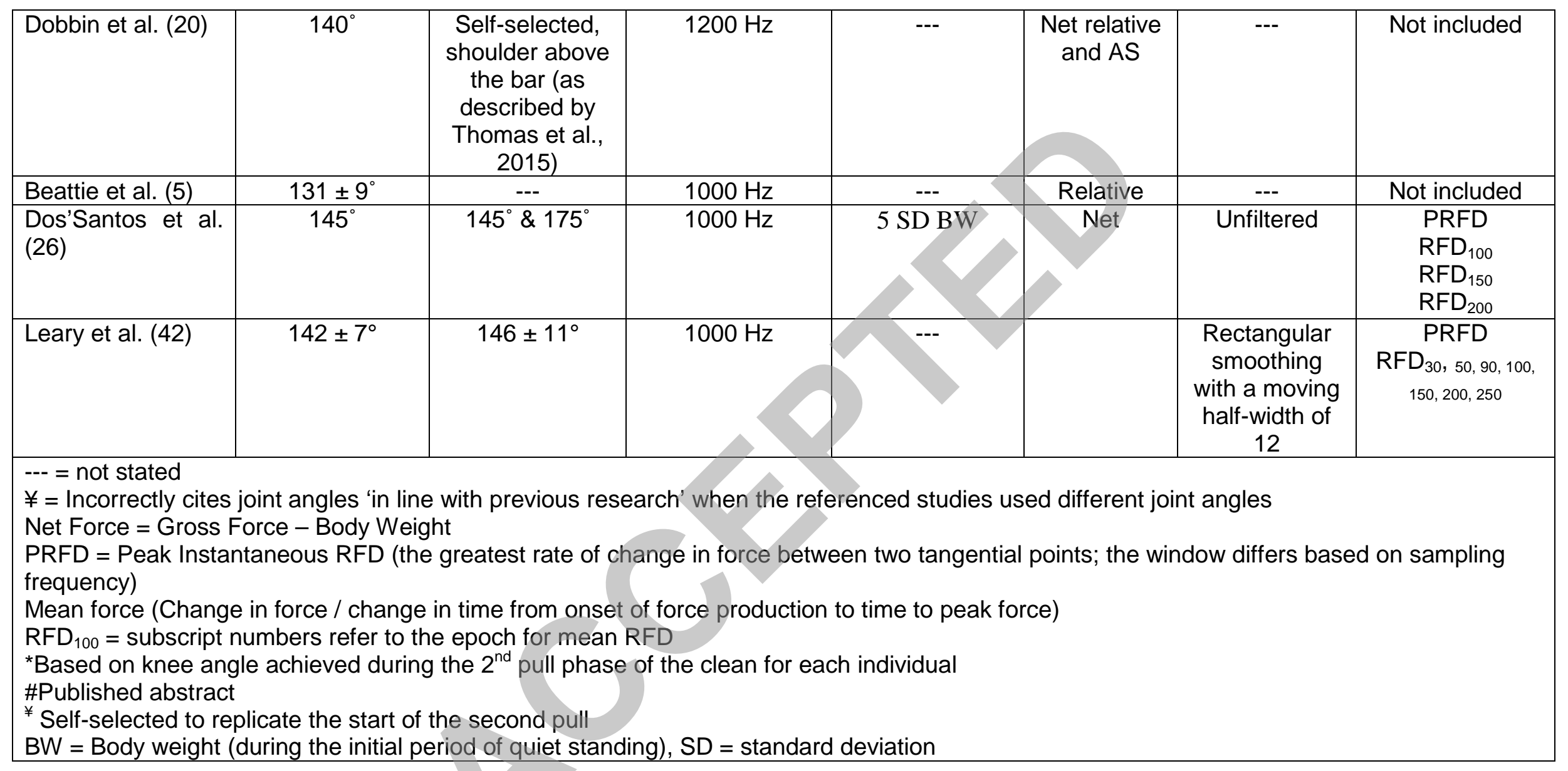




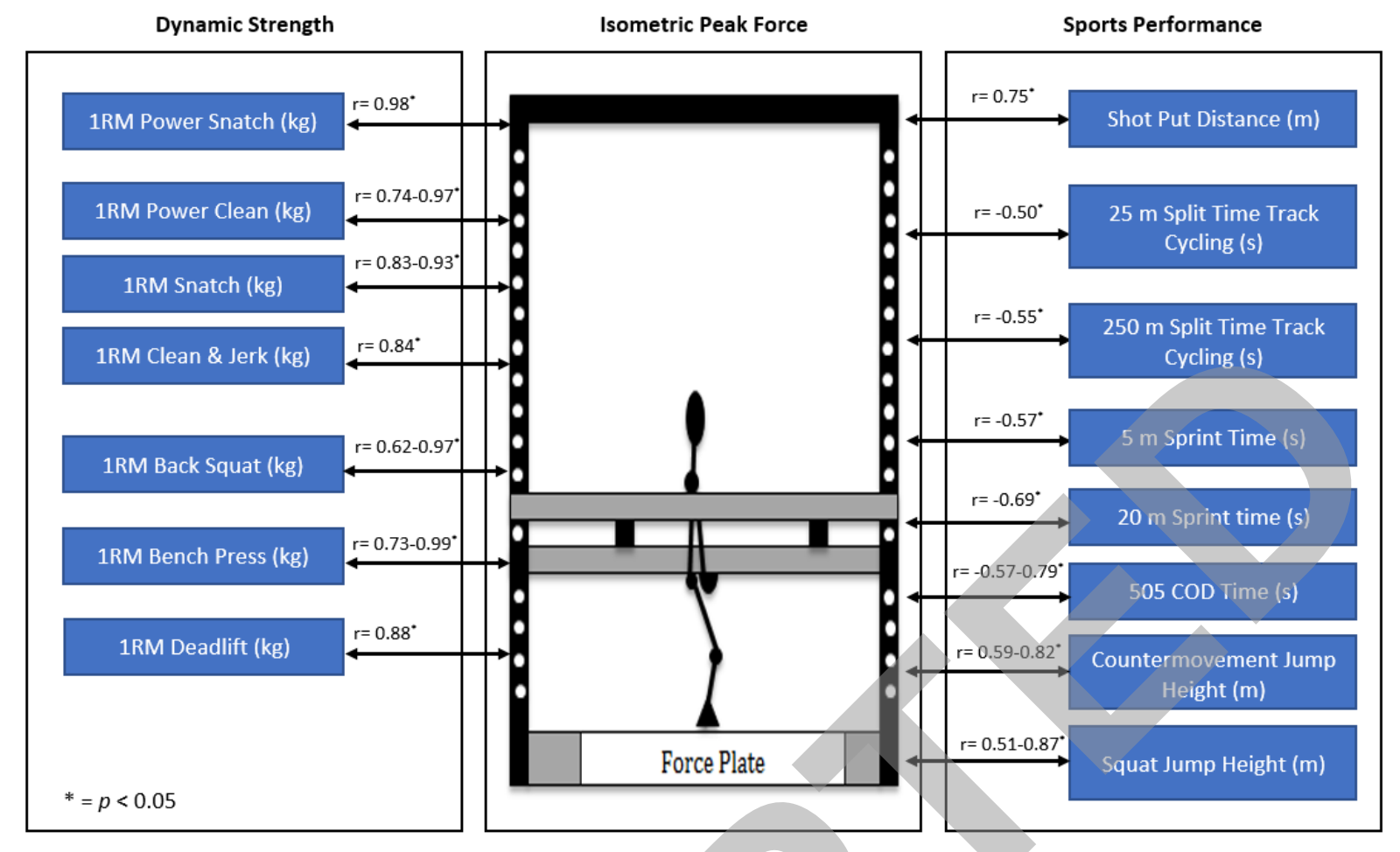

Figure 1: Relationships between isometric mid-thigh pull peak force and performance in other tasks (References in Table 1) 


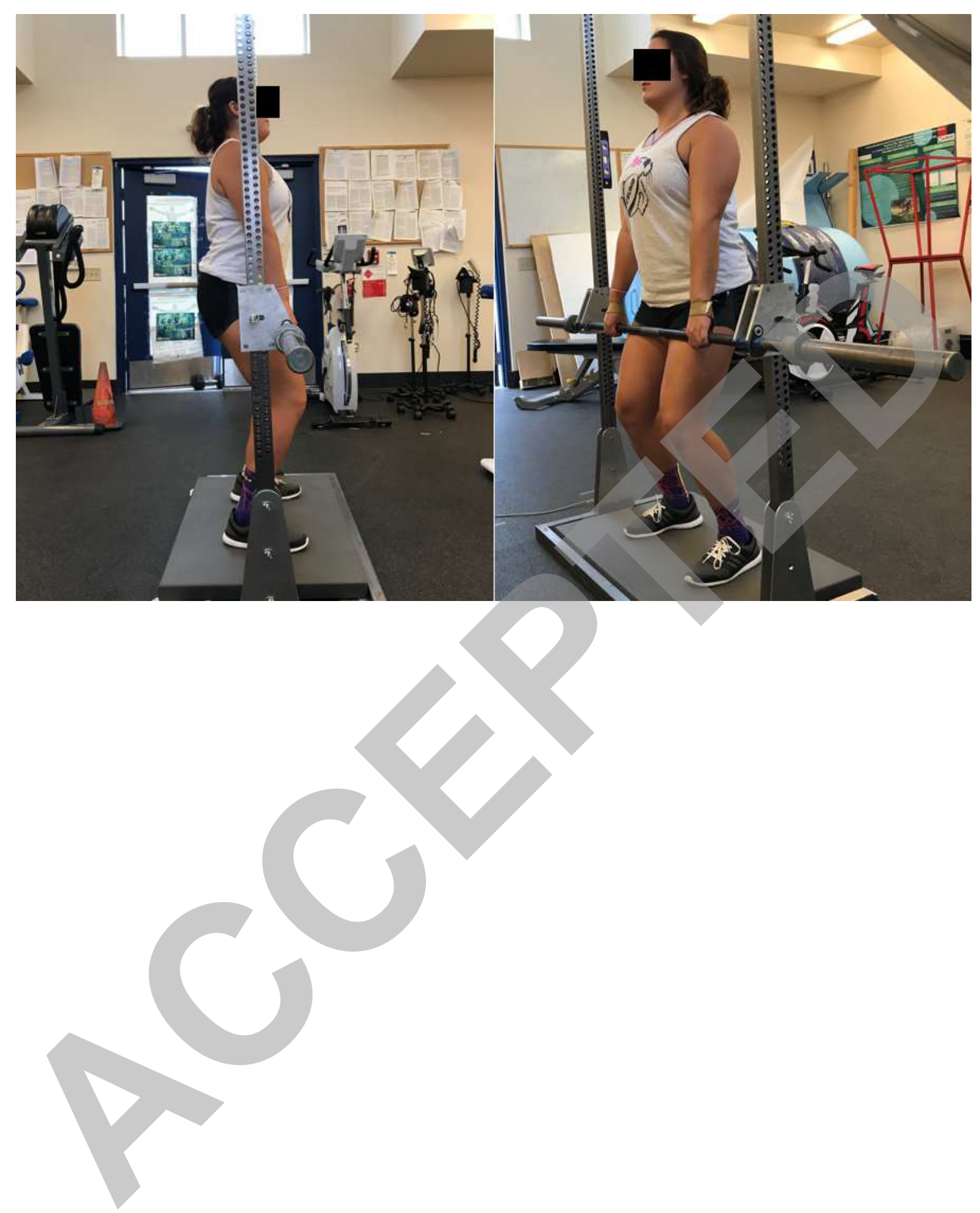


- Bodyweight squats \& lunges

General

Warm-up

- Low load mid-thigh pulls

Dynamic

Warm-up

- Moderate load mid-thigh pulls

- $3 \times 3$ second IMTP trials ( 60 s rest) at

Specific

Warm-Up 50\%, 75\% \& 90\% perceived max' effort

Figure 3: Standardized Warm Up Procedure 


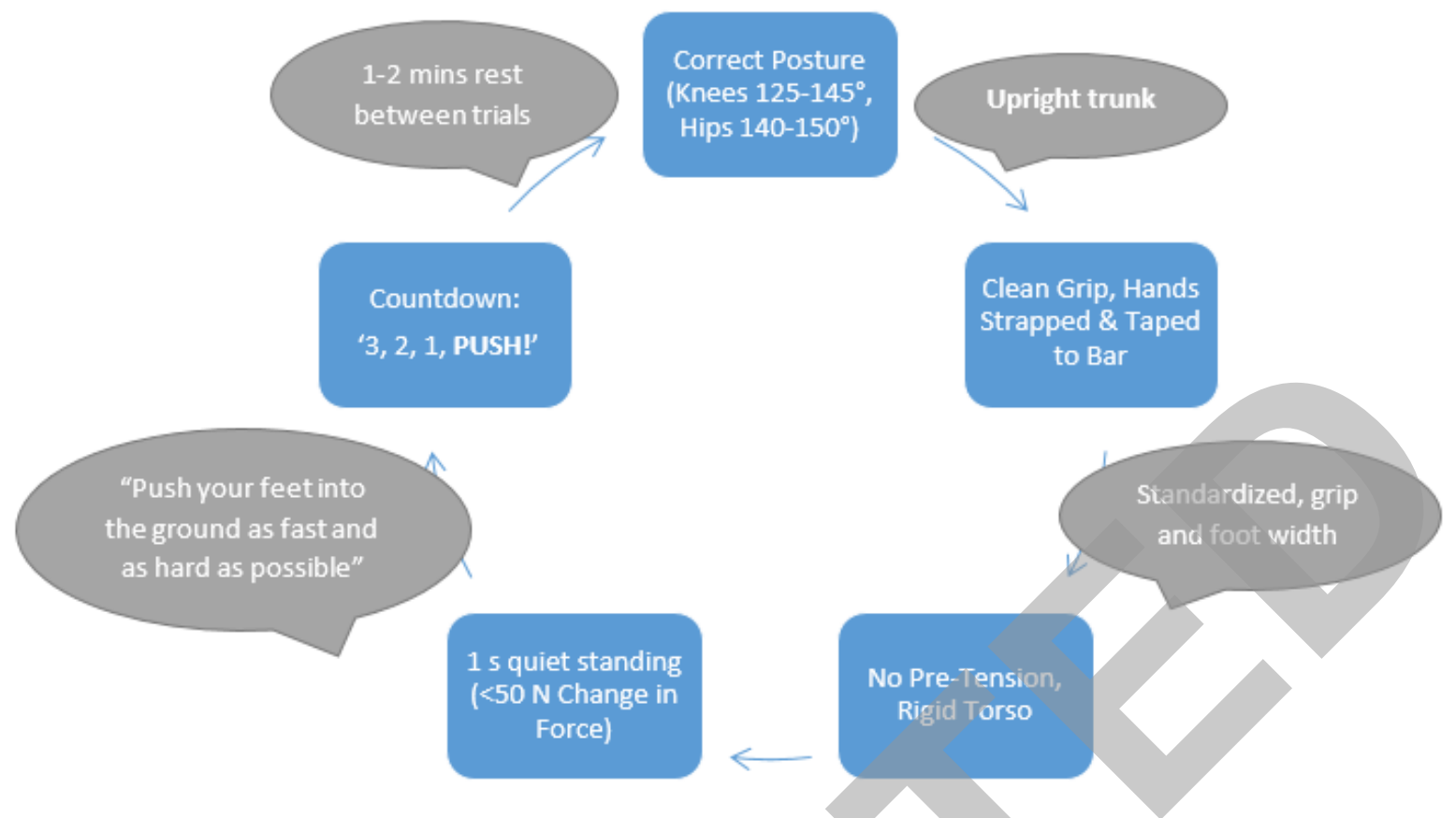

Acceptable trials $<\mathbf{2 5 0} \mathbf{N}$ difference in peak force, minimal pre-tension ( $<\mathbf{5 0} \mathrm{N}$ ) or

countermovement at the start

Figure 4: Standardized isometric mid-thigh pull testing procedure 


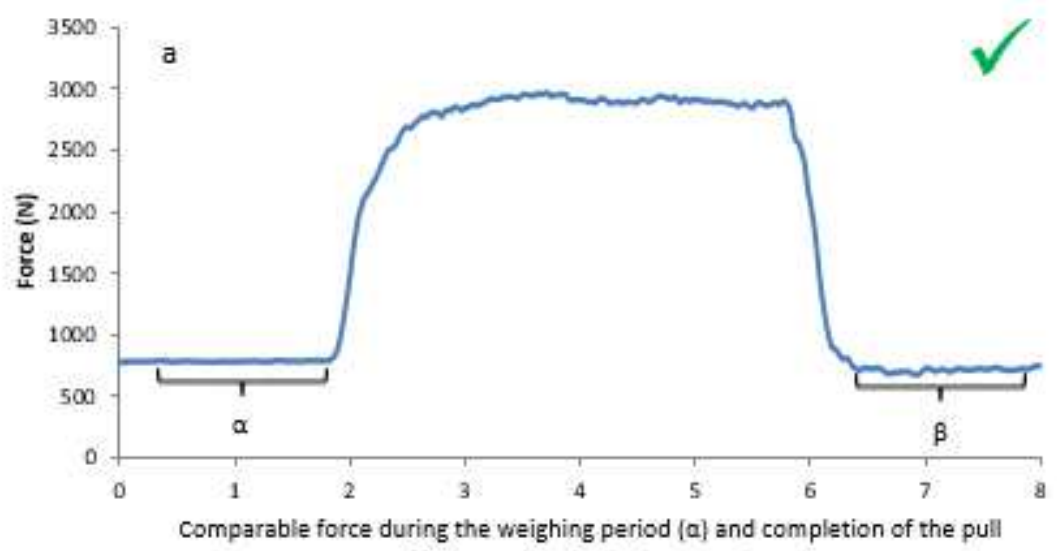

(B), illustrating minimal pre-tension
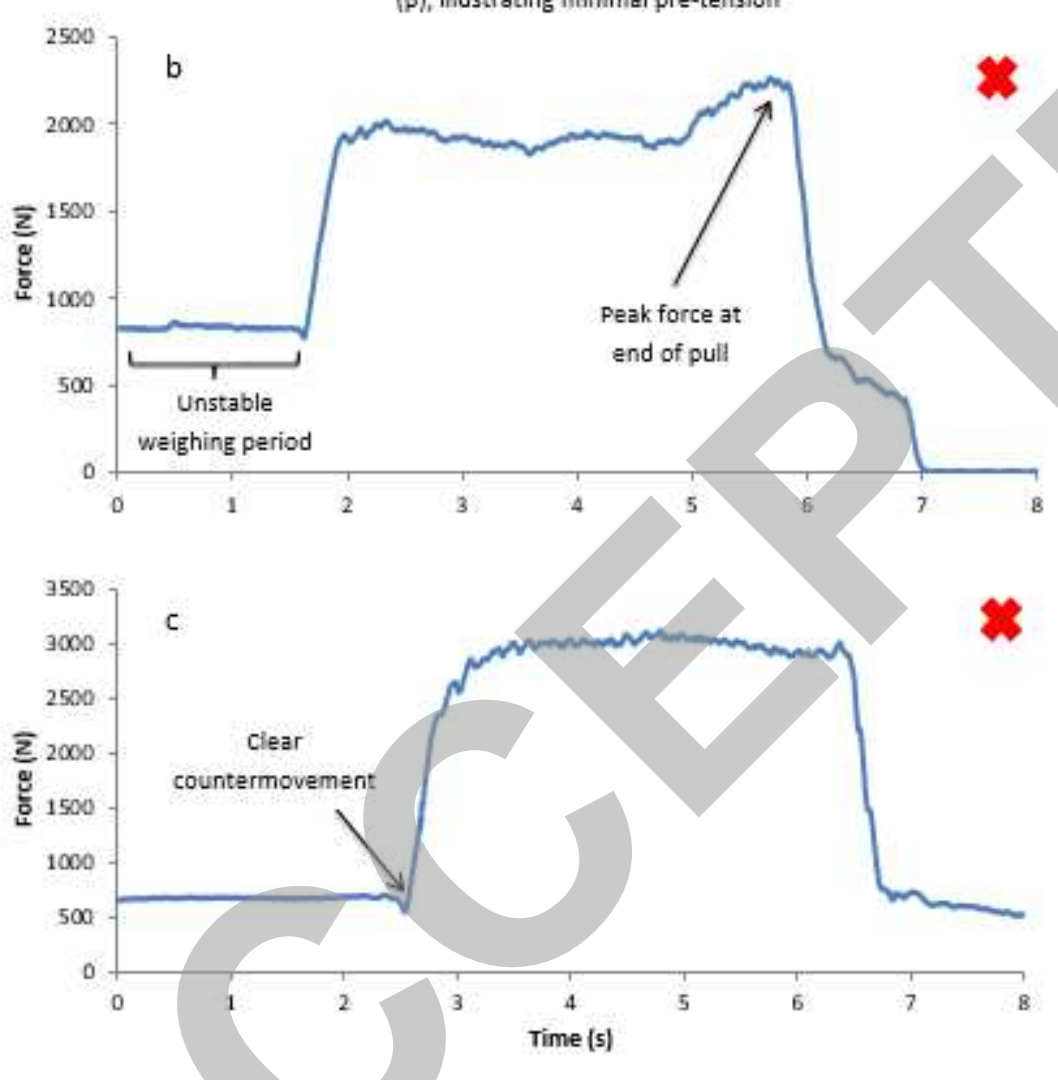

Figure 5: Examples of acceptable and unacceptable isometric mid-thigh pull force-time traces 


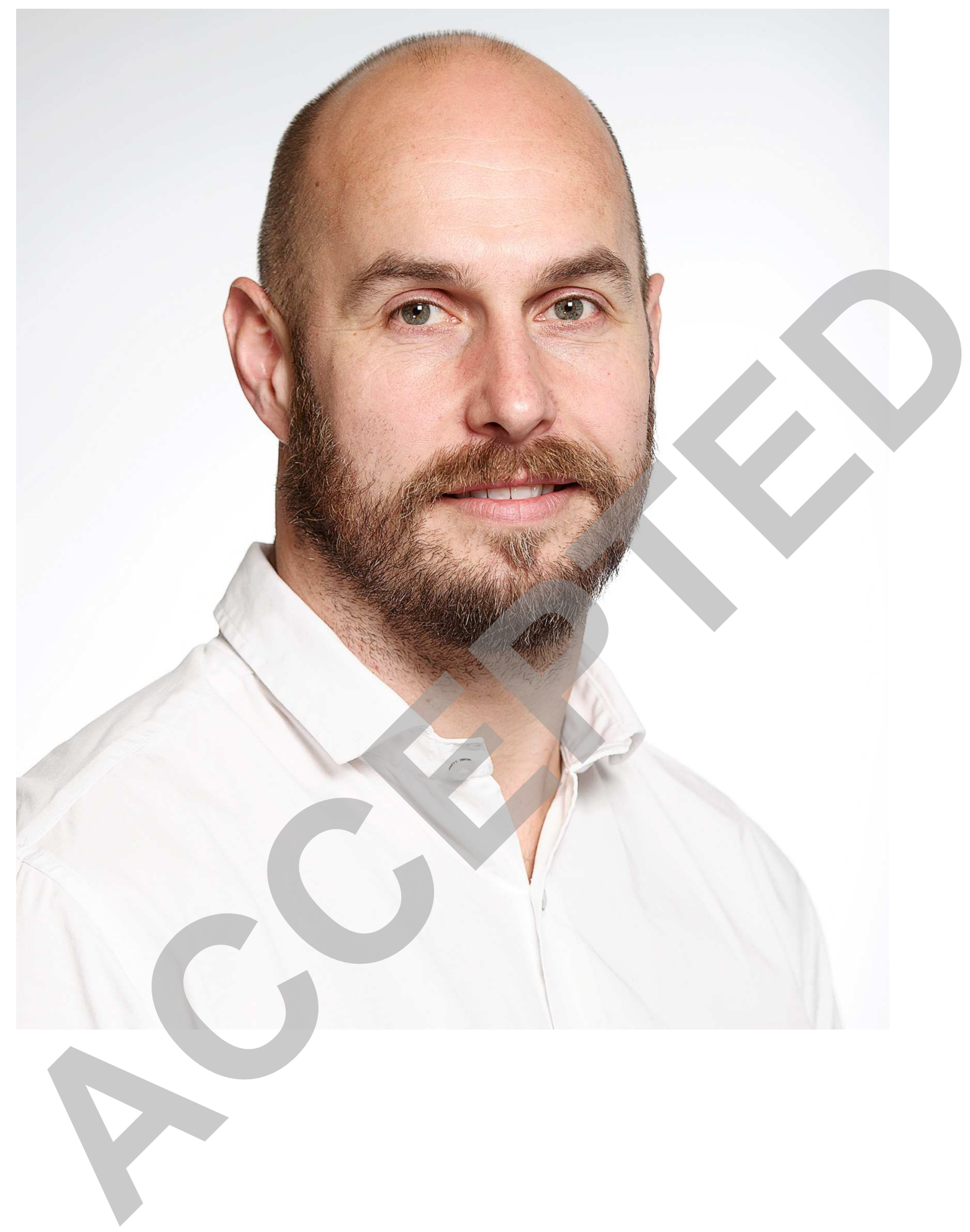

Copyright (c) 2018 Wolters Kluwer Health, Inc. Unauthorized reproduction of this article is prohibited. 


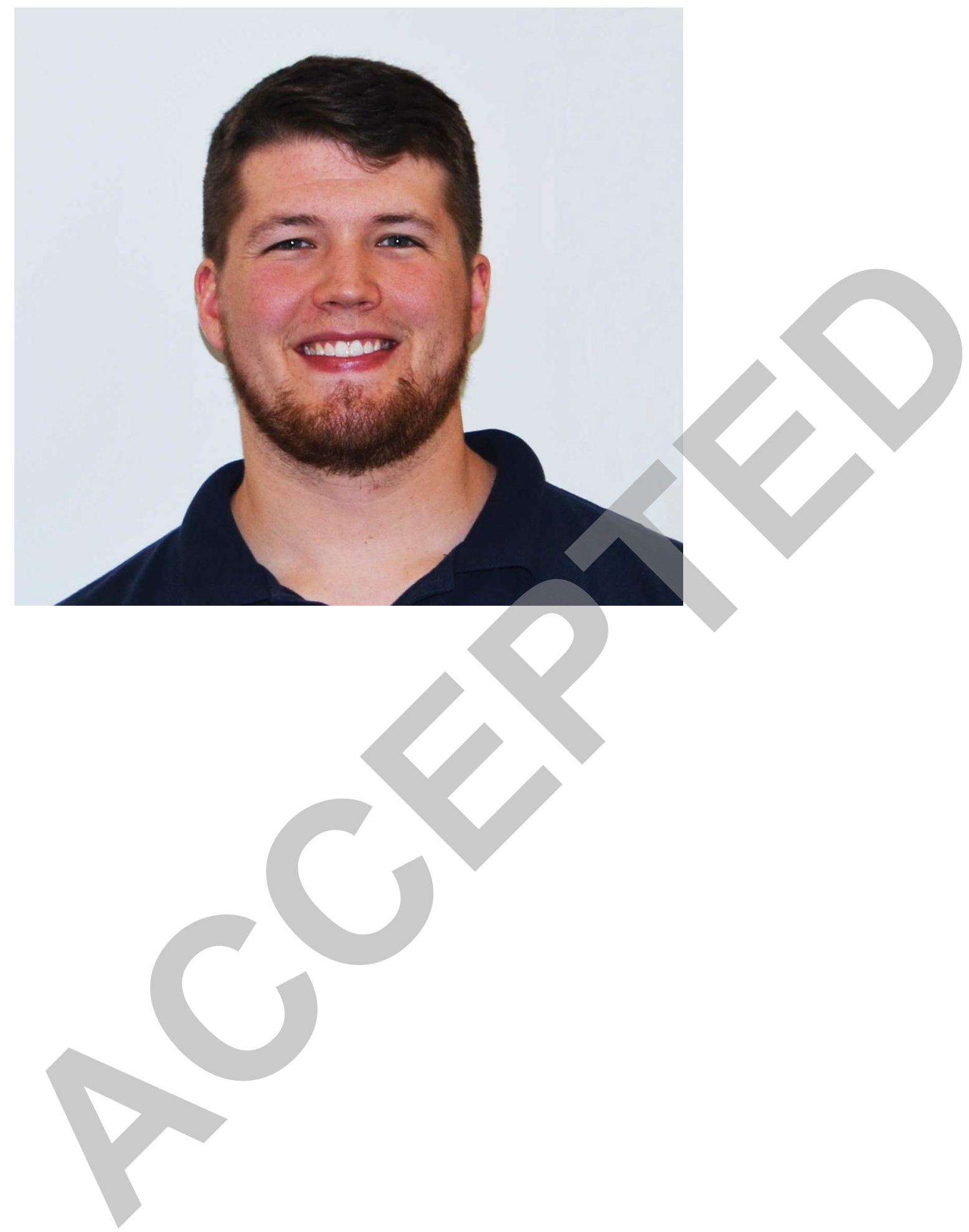

Copyright (c) 2018 Wolters Kluwer Health, Inc. Unauthorized reproduction of this article is prohibited. 


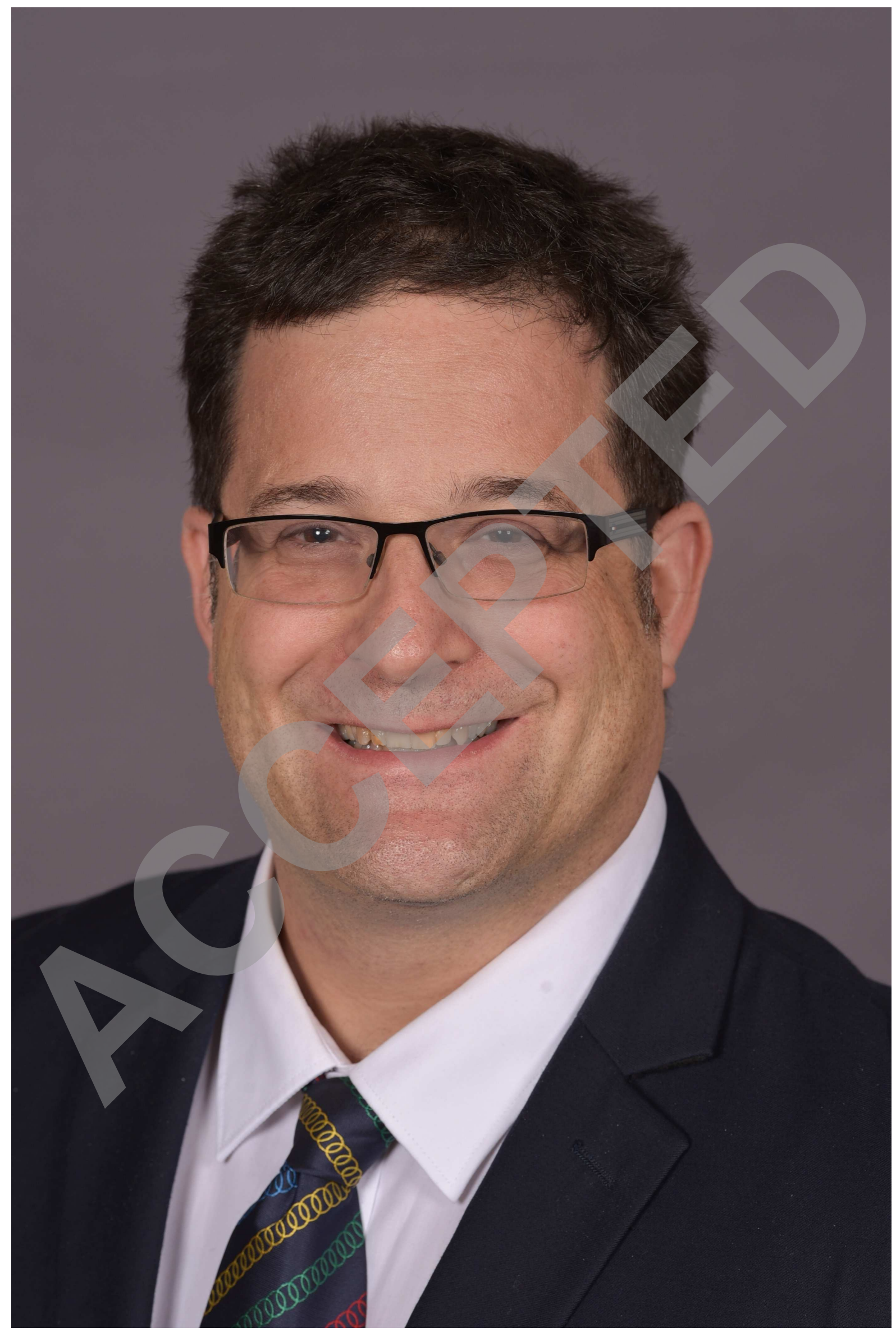

Copyright (c) 2018 Wolters Kluwer Health, Inc. Unauthorized reproduction of this article is prohibited. 


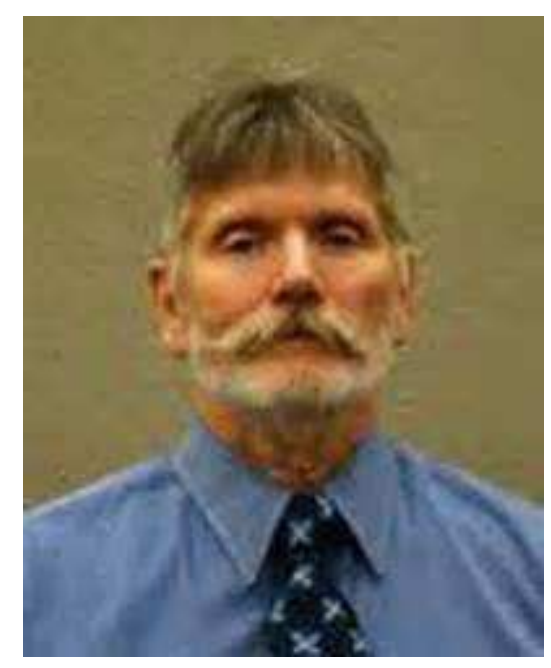




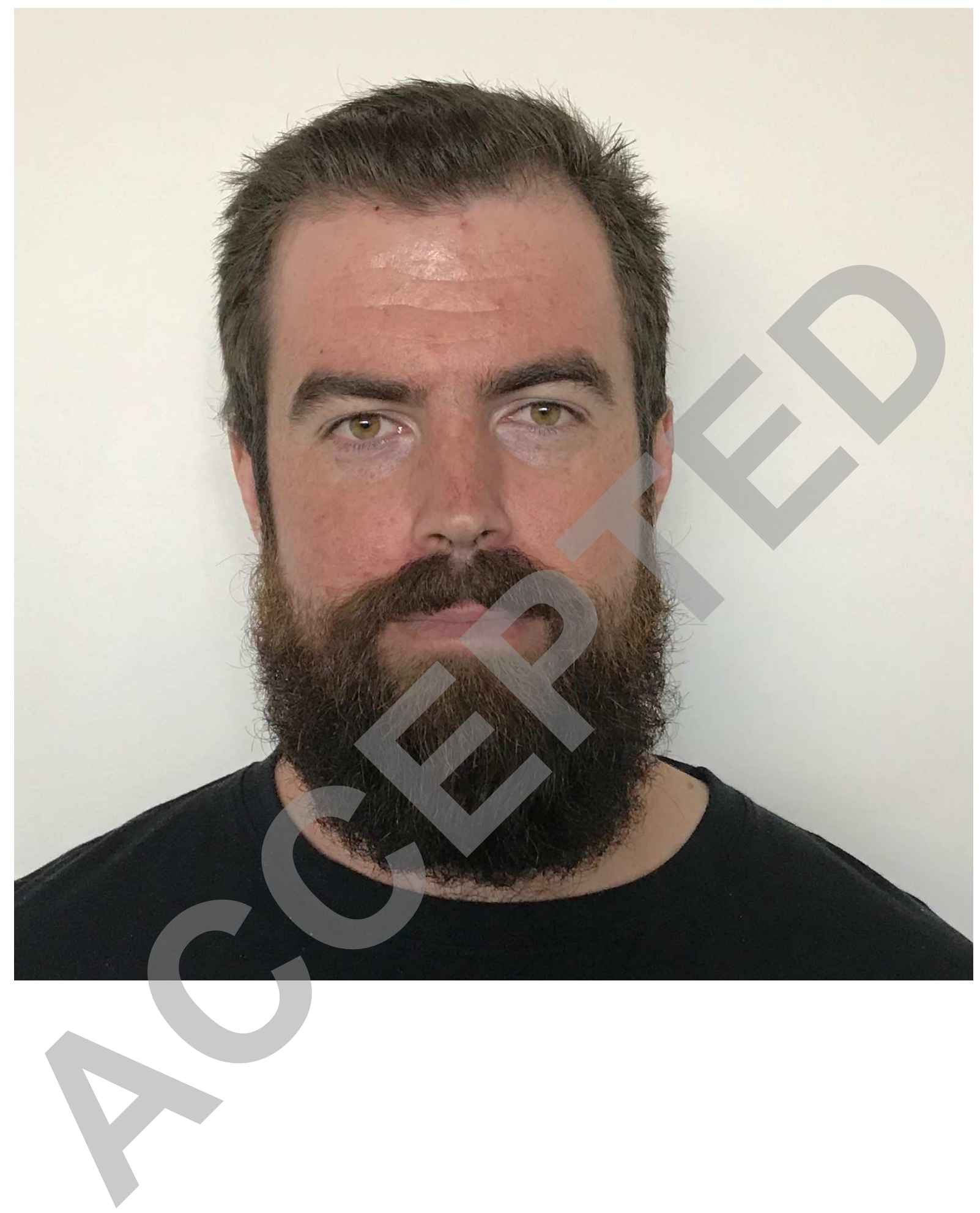

Copyright (C) 2018 Wolters Kluwer Health, Inc. Unauthorized reproduction of this article is prohibited. 

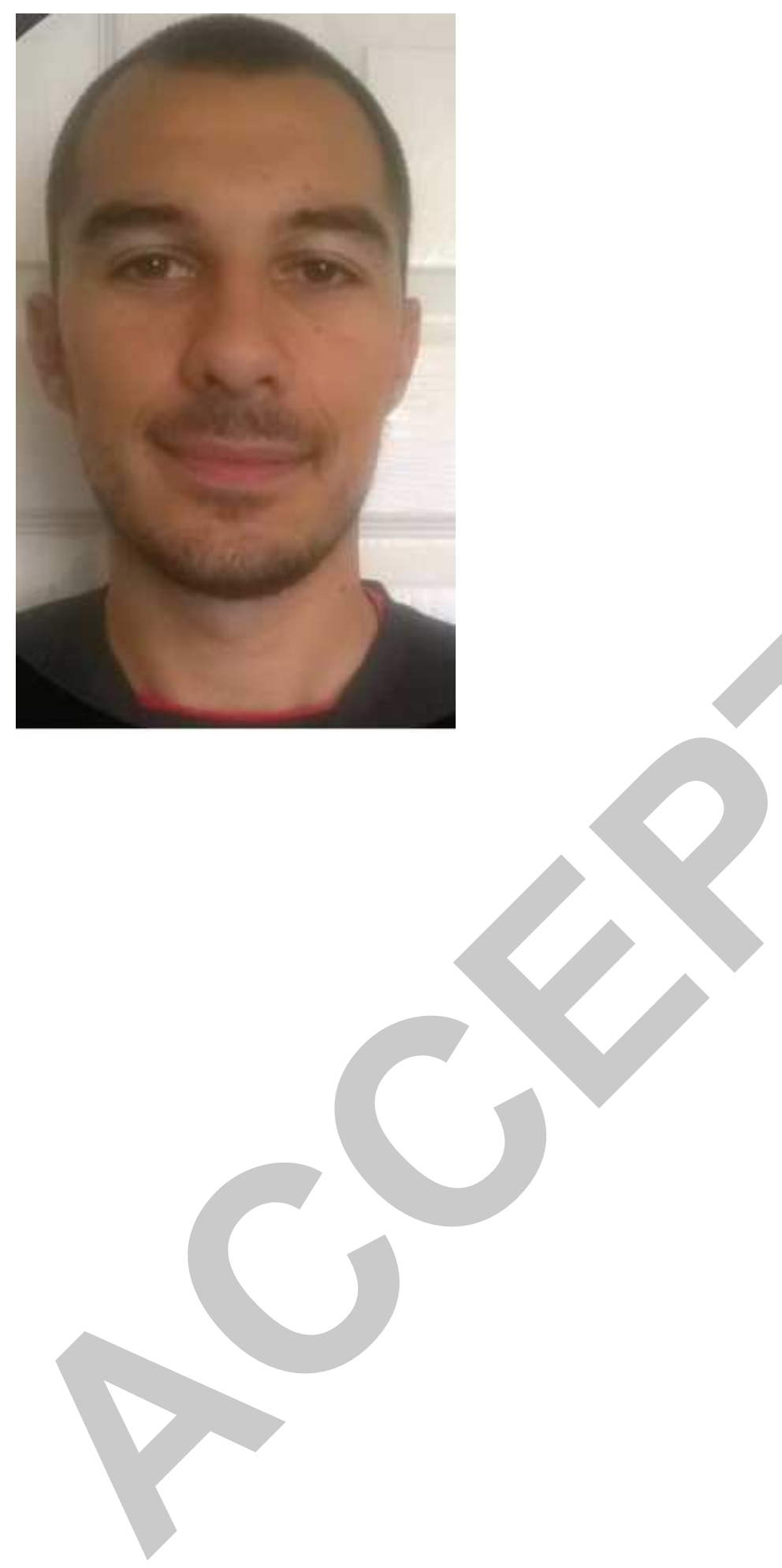

Copyright (c) 2018 Wolters Kluwer Health, Inc. Unauthorized reproduction of this article is prohibited. 